\title{
20. STRUCTURE OF THE OUTER TONGA FOREARC AT SITE $841^{1}$
}

\author{
C.J. MacLeod ${ }^{2}$
}

\begin{abstract}
Ocean Drilling Program Site 841 is located on the outer slope of the Tonga forearc, midway between the crest of the forearc platform and the axis of the Tonga Trench. Drilling revealed a mid Eocene or older rhyolitic basement complex of subaerial origin at a present-day depth of $5.4 \mathrm{~km}$, providing evidence that this part of the forearc must have subsided by that amount since Eocene time.

The purpose of this contribution is to document the structure and history of deformation at Site 841, with the intention of constraining the deformation and ultimately subsidence mechanisms of the outer forearc. The paper is based upon data obtained from both core and Formation MicroScanner logs. Integration of core information with the downhole logs has allowed a more sophisticated structural analysis to be made than is normally possible.

The forearc at Site 841 is dominated by the effects of normal faulting, some of it recent. Two major trench-parallel normal faults, dipping toward the trench axis, cut this section of the forearc; displacement on one of these structures is estimated to be on the order of hundreds of meters. Significant fluid flow channelling through these fault zones has given rise to widespread hydrothermal alteration of the succession.

Analysis of sedimentary bedding orientations from Site 841 shows that a gradual and progressive tilting of the forearc toward the trench has been occurring since Eocene time. An episode of enhanced trenchward tilting took place between 0 and $1.5 \mathrm{Ma}$, almost certainly in response to subduction of the Louisville Seamount Chain beneath this part of the forearc. A small number of reverse faults in the core may indicate minor compression during seamount collision, before the extensional deformation and tilting. The lower, uniform rates of background tilting of the forearc toward the trench axis since the Eocene are probably caused by the progressive tectonic erosion of the base of the forearc. Much of the $5.4 \mathrm{~km}$ of subsidence that has affected Site 841 since Eocene time may be related to the same process.
\end{abstract}

\section{INTRODUCTION}

\section{Regional Setting}

The Tonga Trench is the site of subduction of the Pacific Plate beneath the Indo-Australian Plate. Relative plate convergence is at approximately $15 \mathrm{~cm} / \mathrm{yr}$ (Lonsdale, 1986) and, at $290^{\circ}$, is orthogonal to the $020^{\circ}$ average trend of the trench. At a latitude of approximately $26^{\circ} \mathrm{S}$ a north-northwest-trending chain of guyots and seamounts is entering the trench and is being subducted. The so-called "Louisville Ridge" can be traced across much of the Pacific, parallels the Hawaiian-Emperor chain (Clague and Jarrard, 1973) and has been shown to be hotspot related (Lonsdale, 1988; Watts et al., 1988). Because of the obliquity between the trend of the Louisville Ridge and the convergence direction the collision zone is migrating southward along the trench, at a rate of approximately $18 \mathrm{~cm} / \mathrm{yr}$ (Lonsdale, 1986). In the vicinity of the collision zone the trench axis is unusually shallow, with a maximum depth of less than $6000 \mathrm{~m}$ (Dupont and Herzer, 1985; Pontoise et al., 1986); to the north of it the postcollisional inner trench slope is far steeper (with slopes of $\geq 10^{\circ}$ between 6000 and $9000 \mathrm{~m}$ depth), and the trench axis deeper (10,866 $\mathrm{m}$ in Horizon Deep Bight) than in the Tonga/Kermadec Trench to the south of the intersection, where slopes average $1^{\circ}-2^{\circ}$ and the maximum depth of the trench axis is typically $8000 \mathrm{~m}$ (Fig. 1; Lonsdale, 1986).

\section{Site 841}

Site 841 is located at latitude $23^{\circ} 20.7^{\prime} \mathrm{S}$, longitude $175^{\circ} 17.9^{\prime} \mathrm{W}$, on the outer slope of the Tonga forearc (Figs. 1-2). It was drilled close to the trench-slope break, in $4810 \mathrm{~m}$ of water, at the southern edge of

\footnotetext{
'Hawkins, J., Parson, L., Allan, J., et al., 1994. Proc. ODP, Sci. Results, 135: College Station, TX (Ocean Drilling Program).

${ }^{2}$ Institute of Oceanographic Sciences, Brook Road, Wormley, Surrey GU8 5UB, United Kingdom.
}

a minor north-trending topographic arch (Parson, Hawkins, Allan, et al., 1992). The Horizon Deep Bight, which forms the axis of the Tonga Trench at this latitude, lies approximately $40 \mathrm{~km}$ to the east-southeast, and the crest of the Tonga forearc platform is about $60 \mathrm{~km}$ to the west-northwest. Site 841 lies some $300 \mathrm{~km}$ north of the present-day intersection of the Louisville Ridge with the trench (Fig. 1); hence, assuming constant plate motions, ridge collision and subduction are likely to have affected that portion of the inner trench slope approximately $1.5 \mathrm{Ma}$.

Three holes were drilled at the site. Hole $841 \mathrm{~A}$ was cored initially with a hydraulic piston coring device (APC) to $71.7 \mathrm{mbsf}$, and then with an extended core barrel (XCB) to a total depth of $186.6 \mathrm{mbsf}$. Hole $841 \mathrm{~B}$ was cored with the rotary core barrel (RCB) to a depth of $834.2 \mathrm{mbsf}$, and Hole $841 \mathrm{C}$ was drilled solely for the purpose of logging and was not cored. Logging of Hole $841 \mathrm{C}$ was conducted between 71 and $610 \mathrm{mbsf}$. The holes revealed $605 \mathrm{~m}$ of middle Eocene to Holocene, predominantly volcaniclastic, sediments tectonically overlying remnants of a hitherto unsuspected low-potassium rhyolitic arc complex of middle Eocene or older age. Fauna in the lowermost sediments indicate deposition in shallow-water photic zone conditions, and welding of rhyolitic tuffs suggest eruption in a subaerial environment. Together, these require the site to have subsided by a total of at least $5.4 \mathrm{~km}$ between mid Eocene times and the present day. Detailed descriptions of the cores recovered from Site 841 are given in Parson, Hawkins, Allan, et al. (1992), and in various papers in this volume (e.g., Clift, this volume).

\section{FAULTS WITHIN CORES FROM HOLES 841A AND 841B}

Site 841 is the only site drilled in the Lau backarc basin and Tonga forearc ridge that shows evidence for significant tectonic disruption of the cored succession. Sedimentary bedding is often inclined in excess of $15^{\circ}$, even within a meter of the mud line, and microfaults, with throws of $<1 \mathrm{~mm}$ to several centimeters, are abundant throughout 


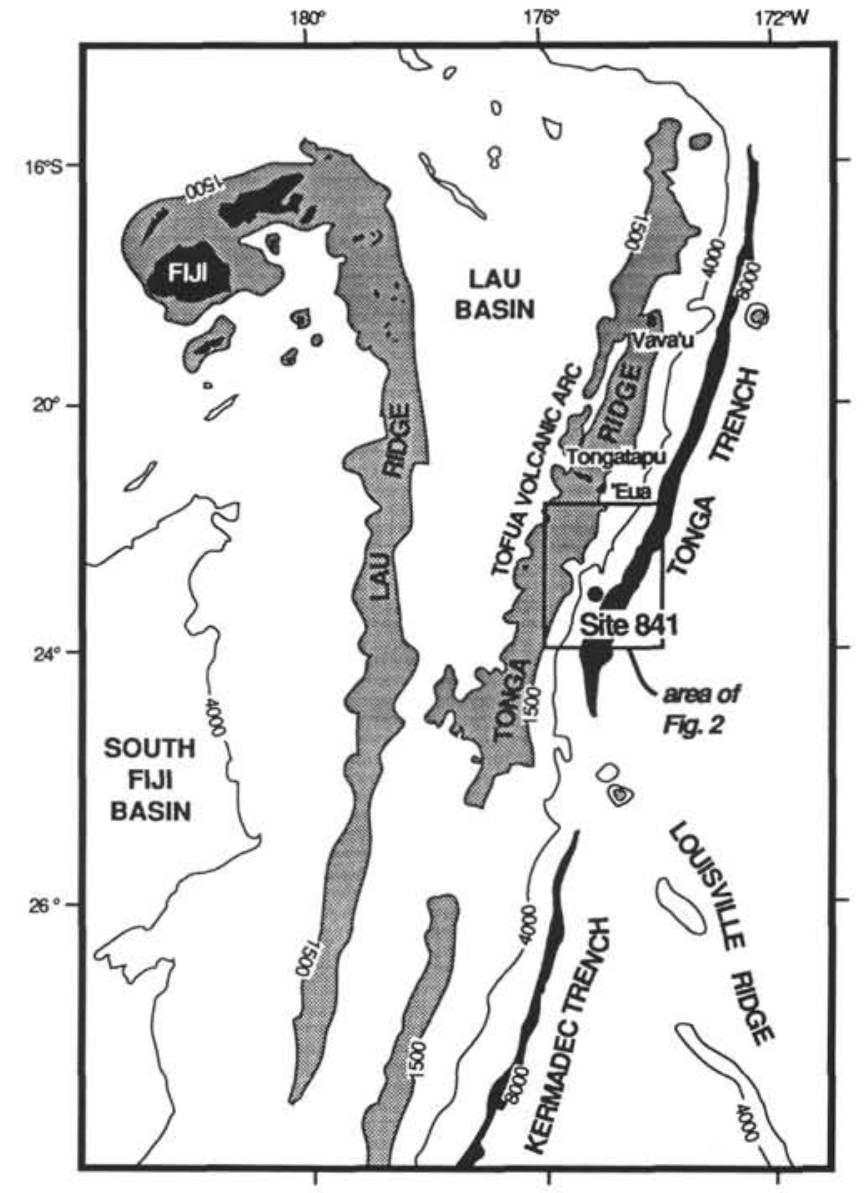

Figure 1. Location map of the Lau Basin and Tonga forearc, southwest Pacific. Subduction of Pacific ocean crust is occurring in the Tonga Trench, and seafloor spreading in the Lau backarc basin is rifting apart the remnant arc complex of the Lau and Tonga ridges. The present-day island-arc chain, the Tofua Arc, is developed on the western edge of the Tonga forearc ridge. The position of Site 841 , on the trench slope of the Tonga forearc, is marked, as is the inset area shown in Figure 2. Land is shown in black, areas shallower than $1500 \mathrm{~m}$ water depth in light shading, and areas deeper than $8000 \mathrm{~m}$ in dark shading.

the sequence. The majority of these microfaults have normal displacements (see examples below) that, when their slip vectors can be determined with precision, are very close to pure dip slip. Normal microfaults have been identified as high in the succession as Core 135-841A-2H (Fig. 3), corresponding to a depth of only $9.3 \mathrm{~m}$ below seafloor (mbsf). Paleomagnetic data suggest that sediment from this depth has reversed polarity consistent with magnetization during the Jaramillo Subchron, of early Pleistocene age (0.7-0.9 Ma; Parson, Hawkins, Allan, et al., 1992). Normal faulting, therefore, must have been taking place in the region at least until early Pleistocene times, and is thought to be continuing at the present day on the evidence of seismic data (von Huene and Scholl, 1991; Parson, Hawkins, Allan, et al., 1992), and GLORIA sidescan sonograph records (Parson et al., 1989; MacLeod and Lothian, this volume).

Brittlely deformed rocks are intersected at several different intervals in the cores from Holes $841 \mathrm{~A}$ and $841 \mathrm{~B}$, and are taken to correspond to fault zones. These zones of deformation are discussed individually in the following section. Two of the zones, described first, are considered to be of significant magnitude as they juxtapose substantially different lithologies, although their actual displacements are not known. The remaining fault zones are not associated with stratigraphic hiatuses, are therefore thought to be associated with lesser displacements, and are described below under the heading "Minor Fault Zones."

\section{Major Fault Zones}

\section{Higher Fault Zone (449-458 mbsf)}

Earthy-textured fault gouge and fault breccia, including epidotebearing fragments of tonalite, are present at the base of Core 135 $841 \mathrm{~B}-31 \mathrm{R}$, and in the uppermost $35 \mathrm{~cm}$ of Core 135-841B-32R (Fig. 4). Only $0.16 \mathrm{~m}$ of rock was recovered from Core 135-841B-31R, and it is possible that faulted rock was present over much of the intervening $9.5 \mathrm{~m}$. This is supported by evidence for significant enlargement of the borehole over the interval on downhole caliper logs from the Formation MicroScanner (FMS) tool (Fig. 5). The fault zone separates upper Miocene volcaniclastic sediments above from earliest middle Miocene volcaniclastic sediments below, omitting three nannofossil and at least seven foraminiferal zones (Parson, Hawkins, Allan, et al., 1992), and implying that the structure had a normal sense of displacement. This is corroborated by the normal offsets on steeply dipping microfaults, sometimes conjugate, that are abundant in adjacent cores.

A rough estimate of the displacement across this portion of the fault may be made by considering the sedimentation rates of the strata on the footwall and hanging wall, and the period of time apparently omitted across the fault. Mean sedimentation rates of upper Miocene volcaniclastic turbidites above the fault were $142 \mathrm{~mm} / \mathrm{k} . y$., and similar, at $160 \mathrm{~mm} / \mathrm{k}$.y. in early middle Miocene volcaniclastics below it (Parson, Hawkins, Allan, et al., 1992). The hanging wall rocks are thought to belong to nannofossil Zones N16 or N17A and foraminifer Zone CN8; those below to Zones N9 and CN4 (Parson, Hawkins, Allan, et al., 1992). Preservation of fauna in these rocks is poor and the zonations are not particularly well-constrained; nevertheless, they imply that approximately 6.5 m.y. of section has been omitted (using the time scale of Berggren et al., 1985); thus, using the sedimentation rates quoted above, the displacement across the fault zone could be as much as a kilometer. G. Chaproniere (pers. comm., 1992) cautions that regional sedimentation rates in mid Miocene times were generally lower than in the early and late Miocene elsewhere on the Tonga Ridge, so this figure may be an overestimate; nevertheless, it gives an indication that the fault zone in Cores 135-841B-31R to -32R had a normal displacement that is likely to be in the order of many hundreds of meters. Note that FMS data, from both calipers (Fig. 5) and borehole electrical images (see below), show that large sections of the borehole (between approximately 360 and $480 \mathrm{mbsf}$ ) are enlarged and might also be affected by significant faulting.

A notable feature associated with the upper fault zone is the extensive hydrothermal alteration that affects footwall sediments for more than $100 \mathrm{~m}$ below the fault zone, but which is almost completely absent in hanging wall strata. Several generations of veins are observed in the footwall sediments. The earliest, and most pervasive, phase of alteration involves the formation of pale halos around veins (Fig. 6) and normal microfaults (Fig. 7). The veins are white, typically very narrow $(<0.5 \mathrm{~mm})$, and filled by a variety of minerals that include quartz, various zeolites and, in places, thaumasite (Schöps and Herzig, this volume, chapter 39). The pale halos around the veins and fractures may be several millimeters wide and appear to be formed by leaching of the volcaniclastic wall-rock rather than by the addition of any other mineral. The leaching is also concentrated along bedding planes, preferentially in the coarser grained sandy sediments, which presumably had higher permeability measurements. The alteration gives rise to a distinctive "zebra-striped" appearance to the rocks and often accentuates original sedimentary structures (Parson, Hawkins, Allan, et al., 1992). Schöps and Herzig (this volume, chapter 39) have shown that the hydrothermal fluids that circulated through these rocks were of relatively low temperature origin (in the approximate range $60^{\circ}-$ $150^{\circ} \mathrm{C}$ ) and derived from seawater. 


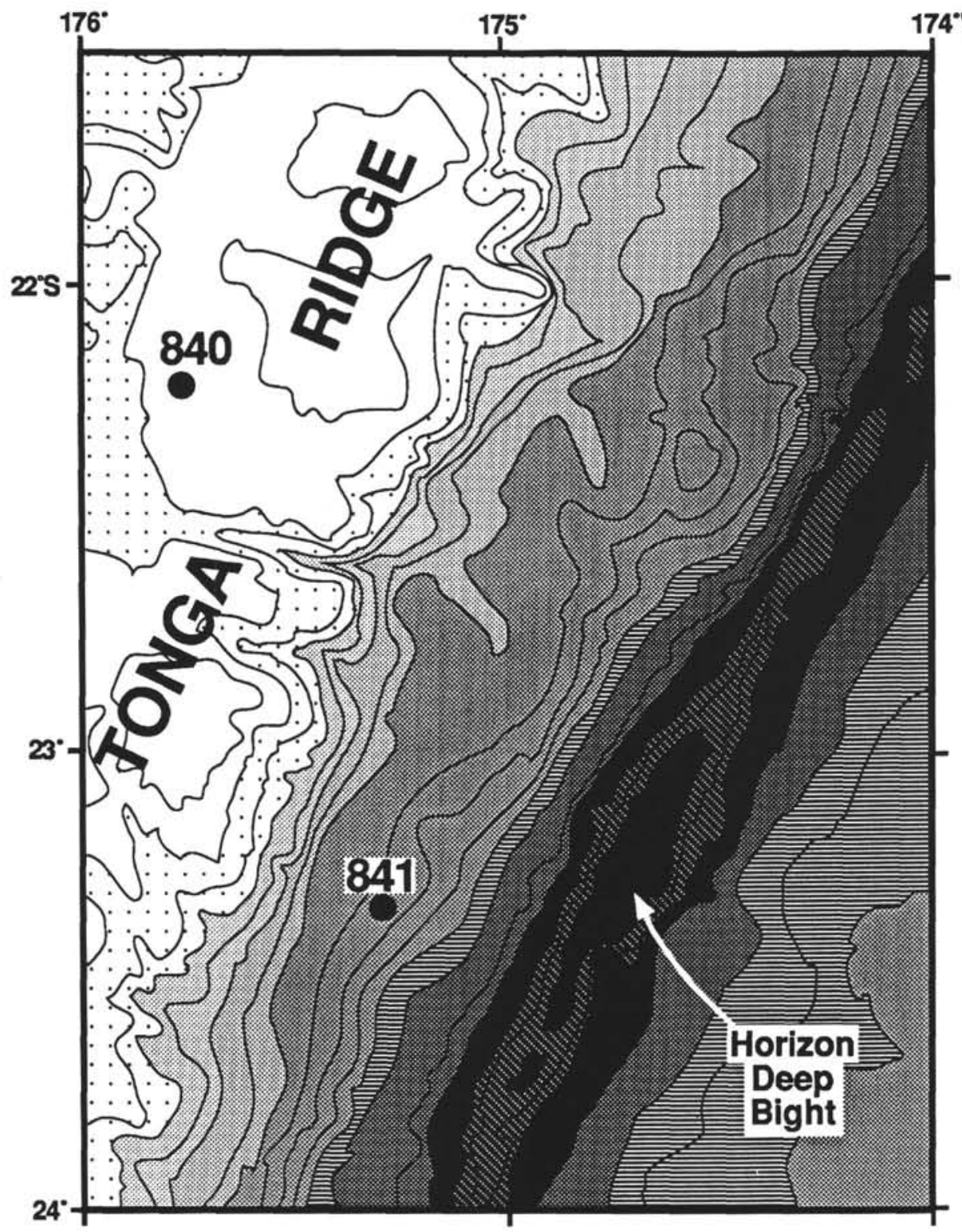

Bathymetry:

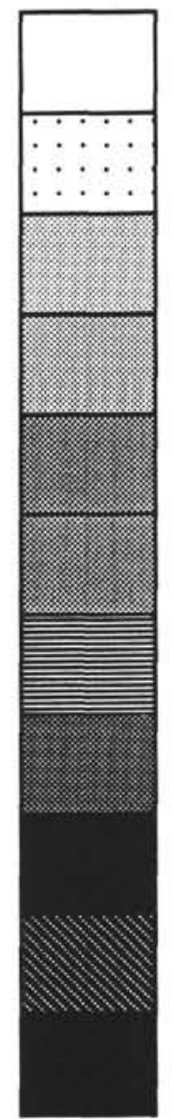

0-1000 m

$1000-2000$

2000-3000

$3000-4000$

4000-5000

5000-6000

$6000-7000$

$7000-8000$

$8000-9000$

$9000-10000$

10000-11000

$100 \mathrm{~km}$

Mercator Projection

Figure 2. Bathymetry of the Tonga forearc and trench, $21^{\circ}-24^{\circ} \mathrm{S}$ (simplified after Parson et al., 1992). Site 841 is located in $4810 \mathrm{~m}$ of water on the inner slope of the Tonga Trench, midway between the axis of the trench (Horizon Deep Bight) and the edge of the forearc platform. The position of Site 840 is shown for reference.

\section{Lower Fault Zone (605 mbsf)}

The second major fault zone in Hole $841 \mathrm{~B}$, located in Section 135-841B-47R-2 (605 mbsf), separates shallow-water calcareous volcanic siltstones of middle Eocene age above from a more than 230 m-thick sequence of rhyolitic tuffs and ignimbrites below. The magnitude and displacement sense of the fault zone is not known, but general stratigraphic relationships and the offset of associated smaller scale faults in Cores 135-841B-44R to -46R, within $30 \mathrm{~m}$ of the fault zone, suggest that it, too, is normal. The uppermost preserved part of the fault zone occurs in Core 135-841B-47R-2 at a depth of $90 \mathrm{~cm}(605.0 \mathrm{mbsf})$, as a $12-\mathrm{cm}$ interval of nonoriented, polished clasts of calcareous siltstone and rhyolite. One rhyolite clast has a foliated cataclastic fabric indicative of high strain. Beneath these clasts $64 \mathrm{~cm}$ of extremely soft white kaolinite- and illite-bearing clay (Schöps and Herzig, this volume, chapter 40) was recovered. The clay contains abundant millimeter-sized quartz grains (often euhedral, with bipyramidal crystal ter- minations), sporadic rhyolitic pumice fragments up to $1 \mathrm{~cm}$ in diameter, and mineralized lithic clasts, including a $2-\mathrm{cm}$ pebble of strained vein quartz, dark grey fine grained rhyolite lava fragments and jasper. The lithic fragments contain disseminated pyrite, and grains of sulfide are dispersed widely throughout the clay. The clay is undeformed except for a narrow, gently dipping schistose shear band in Core 135-841B-47R-2 at 106-109 cm (Fig. 8), and a series of low-angle shear structures in Core 135-841B-47R-CC, 108-127 cm, that appear to be brecciating and disaggregating a preexisting foliated, claybearing fault rock (Fig. 9). Deposition of the soft white mineralized clay, therefore, is thought to be largely post-kinematic, with the exception of the minor fault strands described above: the shear strength of the clay appears to be so low that it would have been obliterated by any significant displacement along the fault zone. The above observations suggest that the white clay is a hydrothermal deposit rather than the rhyolite fault gouge suggested by Parson, Hawkins, Allan, et al. (1992). 


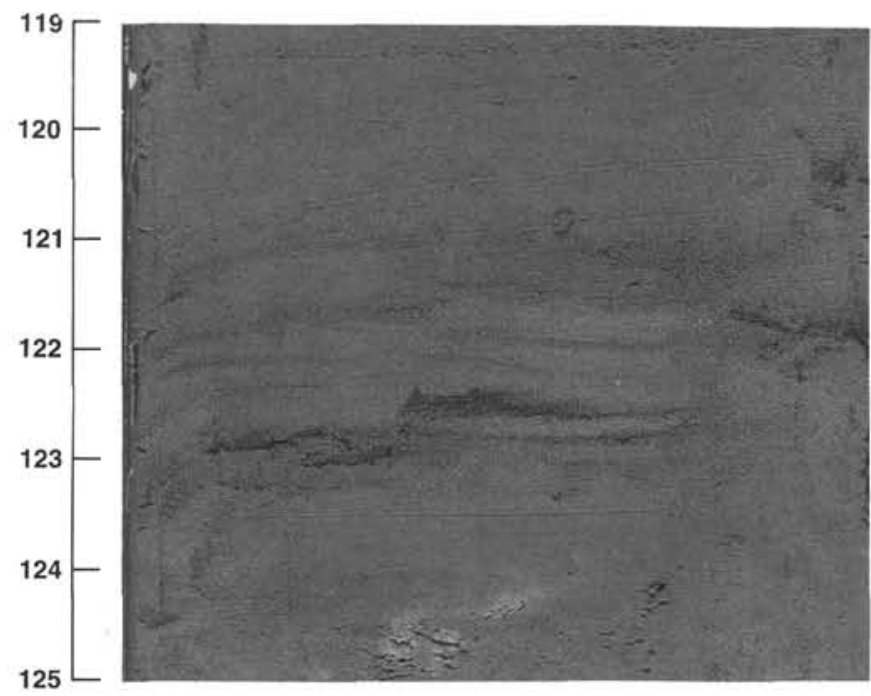

Figure 3. Microfaults with normal senses of motion in lower Pleistocene clays. Core $135-841 \mathrm{~A}-2 \mathrm{H}-4,119-125 \mathrm{~cm}$.

Hydrothermal alteration of the footwall of the lower fault zone is intense. Petrologic evidence, coupled with $\mathrm{SiO}_{2}$ contents of more than $80 \%$ in rhyolites just beneath the fault, suggest significant silicification of the footwall. As with the upper fault zone, sediments in the hanging wall are not much affected. At present, there is no way of saying whether the absence of significant alteration in the hanging wall is a function of the original geometry of the hydrothermal circulation system, or whether the evidence has simply been removed by displacement on the fault. Schöps and Herzig (this volume, chapter 40) have shown that the intensity of alteration diminishes downsection in the footwall; that is, away from the influence of the fault. These authors report hematite and clinochlore (Mg-rich chlorite), which form in oxidizing environments from the fault zone itself, in contrast to the alteration assemblages from the rest of the rhyolite complex, which are instead characteristic of low oxygen and sulfur fugacity (reducing) conditions. Chlorite formation temperatures and quartz fluid inclusion temperatures fall within a range from $265^{\circ}$ to $300^{\circ} \mathrm{C}$ for the whole rhyolite sequence, including the fault zone. However, lower temperature minerals are also present: the composition of pyrrhotite grains requires temperatures $<250^{\circ} \mathrm{C}$, and the illite and kaolinite from the white clay within the fault zone at $605 \mathrm{mbsf}$ require formation at $<200^{\circ} \mathrm{C}$ (Schöps and Herzig, this volume, chapter 40). The low temperature of the white clay supports the observation, made above, that it is a hydrothermal deposit that largely postdates motion on the fault zone.

The nature of the hydrothermal fluids from both the lower and upper fault zones is of considerable interest, given the position of Site 841 so close to the Tonga subduction zone. Large volumes of fluid are known to be driven off subducting slabs and to affect forearc regions in particular (e.g., Peacock, 1990; von Huene and Scholl, 1991). Could such fluids have been channelled up the major fault zones at Site 841? Direct evidence for the chemical composition of volatiles derived from subducting slabs is limited, but Mottl (1992) has shown that pore fluids of demonstrable subduction origin from serpentinite seamounts in the Mariana and Izu-Bonin outer forearcs have pronounced depletions in chloride and enrichments in methane and ammonia. Their compositions have been modified significantly from that of seawater, are strongly reducing, and, thus, are very different from the inferred composition of the hydrothermal fluids that circulated through the Site 841 fault zones. For Site 841, therefore, seawater would appear to be the more likely parent fluid.

\section{Minor Fault Zones}

Minor fault zones are defined for the purposes of this discussion as those intervals within the core over which fault rock or significant

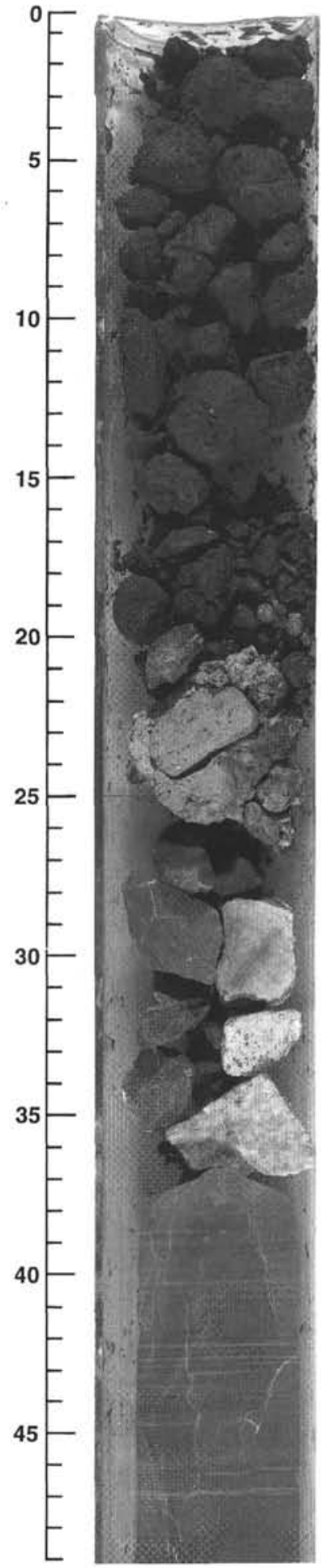

Figure 4. Recovered fault rock from the major fault zone at $458 \mathrm{mbsf}$. The pale clast at $22-24 \mathrm{~cm}$ contains epidote. Note veining and normal faulting in laminated volcaniclastic sediments beneath the fault rocks. Core 135-841B$32 \mathrm{R}-1,0-49 \mathrm{~cm}$.

shattering of the core (demonstrably predrilling) has been recognized and whose displacement is greater than the scale of the core, but which do not give rise to detectable hiatuses or repetitions of the stratigraphic sequence. Therefore, they are assumed to be of lesser magnitude than those structures described in the previous section, although this assumption need not be valid if the lithologies are homogeneous. They 


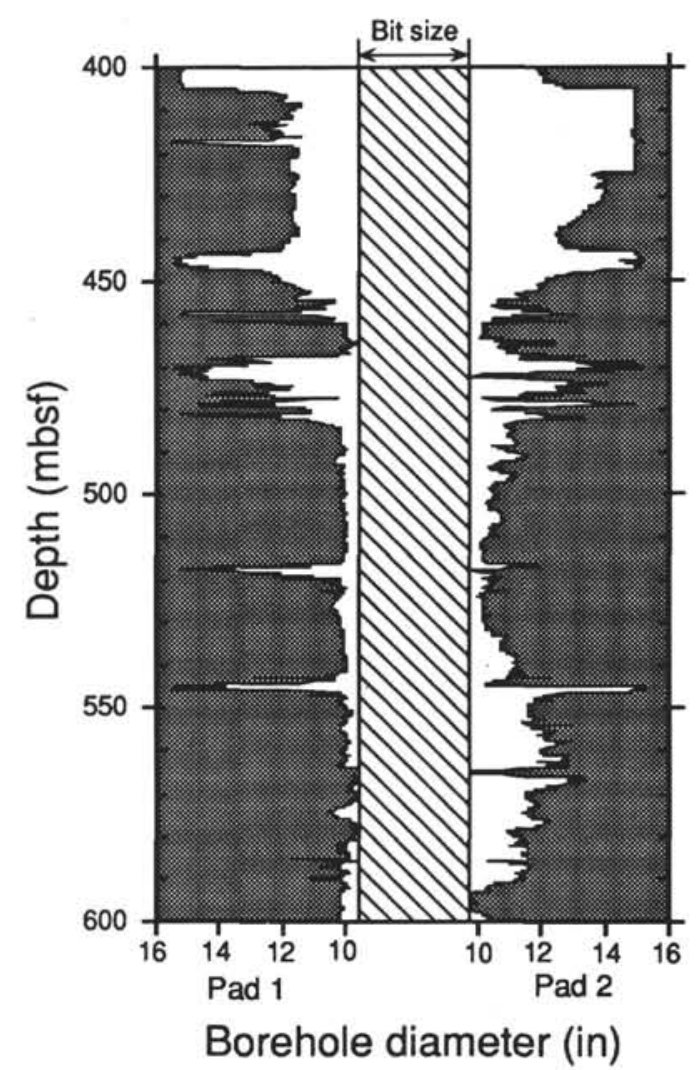

Figure 5. FMS caliper plot (Run 2) for Hole 841C, 400-600 mbsf. Pads 1 and 2 are two orthogonal borehole diameter measurements; differences between the two indicate that the borehole is elliptical in that interval. Hole ellipticity is often a consequence of differential horizontal in situ stresses, and is discussed further for these data by MacLeod and Pratt (this volume). Sudden increases of borehole size, however, usually measured by both pads, are often indicative of faults intersecting the borehole. Enlarged intervals between 440 and $480 \mathrm{mbsf}$, for example, are probably associated with the upper fault zone encountered in the core from Hole $841 \mathrm{~B}$ at $\sim 450 \mathrm{mbsf}$ (see text).

are envisaged to be comparable in magnitude to outcrop-scale mesofaults that have displacements on the order of tens of centimeters to tens of meters.

\section{Section 135-841B-36R-1, 87-120 cm (497.7-498.0 mbsf)}

A total of $33 \mathrm{~cm}$ of indurated foliated fault rock was recovered from lithostratigraphic Unit IV (Parson, Hawkins, Allan, et al., 1992), at a depth of $498 \mathrm{mbsf}$ (Fig. 10). The fault rock is a "foliated cataclasite" (following the definition of Chester et al., 1985), and has shear fabrics indicating normal displacements under brittle deformation conditions. The fault rocks lie within the zone of leaching described above in the footwall of the fault zone at 449-458 mbsf, and have themselves been heavily modified by hydrothermal alteration, in the form of cross-cutting anastomosing veins of quartz and zeolites. It is likely that the minor fault zone at $498 \mathrm{mbsf}$ is a subsidiary to the major structure that lies $40 \mathrm{~m}$ above it.

\section{Sections 135-841B-44R-1 to -46R-2 ( $574-595 \mathrm{mbsf})$}

Minor faults are distributed throughout the $25-30 \mathrm{~m}$ of core that lie above the major mineralized fault zone at $605 \mathrm{mbsf}$. Slickensides are common, and many surfaces are coated with soft talc-like clay mineral. Where the core is sufficiently coherent for the orientation of fractures relative to the borehole axis to be measured, the striations fall on steeply dipping planes and display almost pure dip-slip normal senses of motion.

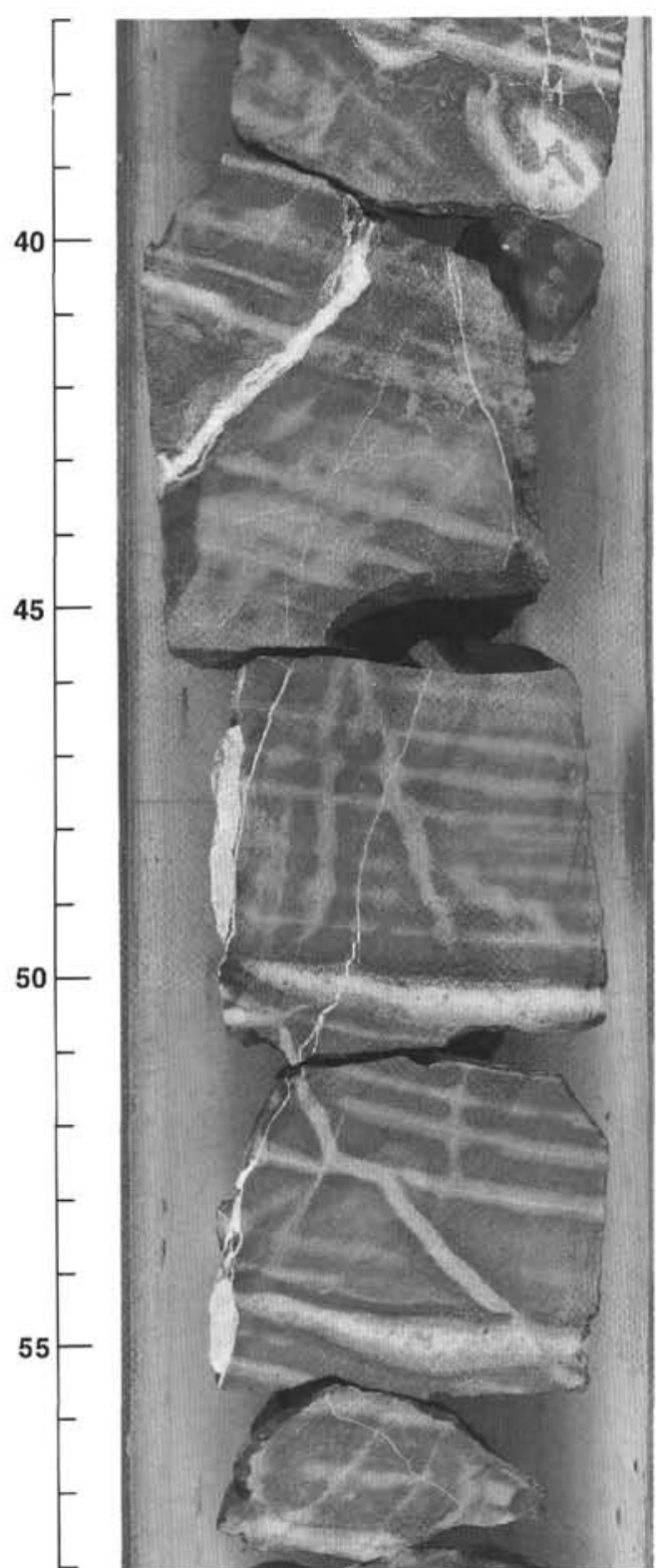

Figure 6. Hydrothermal alteration associated with the lower fault zone. Two generations of veins are present here: an earlier set of narrow veins (probably quartz-zeolite, possibly with thaumasite), are associated with leaching of the volcaniclastic silts to a pale color (note that leaching also occurs along bedding planes, preferentially along coarser grained sediment layers); and a later generation of broader white veins cuts both the bedding and earlier leaching. Core 135-841B-33R-2, 38-57 cm.

\section{Section 135-841B-51R-3 (645 mbsf)}

In Section 135-841B-51R-3 coherent but hydrothermally altered green rhyolitic tuffs at the top of the section change abruptly to a crushed gouge, formed of comminuted fragments of the same lithology. No discrete fracture planes were observed at or close to the transition from competent to crushed rock, but a fault zone is the most reasonable explanation for the sudden transition.

\section{Section 135-841B-63R-1 (757 mbsf)}

Core $135-841 \mathrm{~B}-63 \mathrm{R}$ marked the transition to very poor recovery at the base of Hole $841 \mathrm{~B}$. Whereas $1.79 \mathrm{~m}$ of core was recovered from 


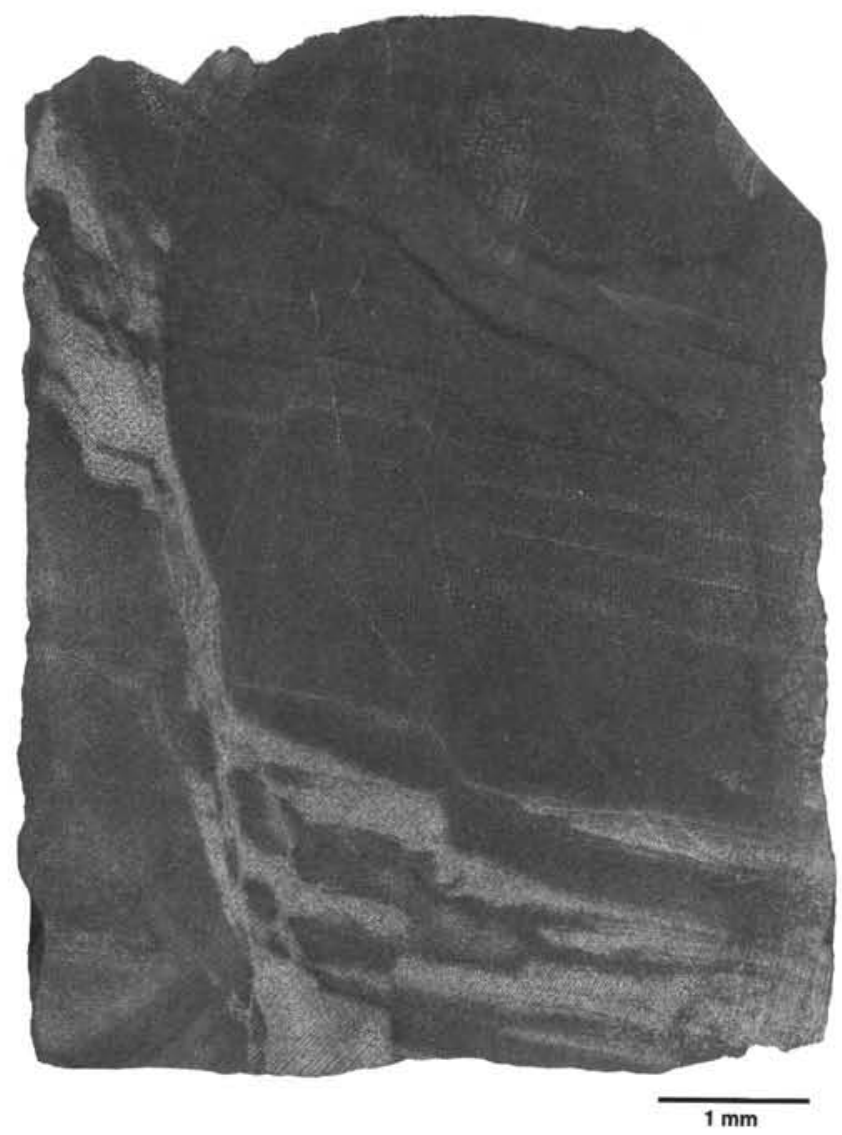

Figure 7. Leaching associated with a normal microfault, demonstrating that motion on the fault predated or was coeval with leaching. Note the slight normal faulting either side of a small horst structure in the center of the piece: these tiny faults form a conjugate pair. Core 135-841B-34R-2, 12-20 cm.

Core $135-841 \mathrm{~B}-63 \mathrm{R}$, only $1.3 \mathrm{~m}$ in total was recovered from the remaining seven cores (with $67.7 \mathrm{~m}$ of penetration) drilled at Hole $841 \mathrm{~B}$, and unstable rock conditions caused termination of the hole at 834.2 mbsf. Core 135-841B-63R itself, which is made up of greenish tuffaceous breccia, is cut by a large number of fault strands and associated gouge throughout. A number of discrete fracture planes are preserved, dipping steeply with respect to the axis of the borehole, and a pair of conjugate normal faults with moderately to steeply plunging slickenside surfaces was recognized. The loss of recovery beneath Core 135-841B-63R may be an indication that the brittle fracturing continues down to the base of the hole.

\section{Normal Microfaults}

Although not strictly correct, it is convenient for the purposes of this paper to refer to faults with displacements less than the diameter of the borehole as "microfaults." Such microfaults are extremely abundant within the recovered core. They almost all show pure dip-slip slickensides, where measurable, the majority with normal senses of offset ( $72 \%$ of the total of 214 microfaults measured in Holes $841 \mathrm{~A}$ and $841 \mathrm{~B}$, or $80 \%$ of those with identifiable displacements; Fig. 11). The normal microfaults are often spatially associated with the larger fault zones; many such microfaults have been healed by the associated mineralization, and have clearly been the loci of significant fluid flow (e.g., Fig. 7). The angle between the microfaults and the bedding is typically rather high: many are oriented almost perpendicular to the bedding (Fig. 12).
In addition to those structures with identifiable normal displacements, other obviously extensional features are observed in the core. Clastic or "neptunean" dikes are fairly common throughout the sedimentary section of the borehole, forming sand-filled cracks up to 1-2 $\mathrm{mm}$ wide within clay-rich strata. All of the neptunean dikes are disposed approximately perpendicular to the bedding. Downward injection from an overlying sandy layer is observed in some instances (Fig. 13). In Figure 13, offset of the neptunean dike by a few millimeters is an indication of an otherwise unsuspected bedding parallel shear. Neptunean dikes clearly result from bedding-parallel extension in sediments that are barely lithified, perhaps under conditions of high fluid pressure.

Regular, parallel, dark-stained, clay-rich surfaces, also oriented perpendicular to the bedding (Fig. 14), may be observed in some finegrained sediments. These were termed "vein structures" by Lundberg and Moore (1986), and they have been interpreted by Cowan (1982) and by Lundberg and Moore as tensional fractures formed in response to layer-parallel extension in barely lithified sediment, in the same manner as the neptunean dikes.

\section{Reverse Microfaults}

Reverse displacements were observed on some microfaults (Figs. 15-17), although they are by far in the minority (Fig. 11). Some apparent reversed senses of motion on steeply dipping microfaults are actually normal with respect to the sedimentary bedding (see Figs. 16 and 12) and therefore are interpreted as tilted normal faults. However, reverse motion on the remainder of the microfaults (forming $9.8 \%$ of the total), some of which dip at a shallow angle, cannot be explained in this manner and appears to represent genuine evidence for compressional faulting, albeit perhaps localized. The true reverse microfaults appear to be restricted to the approximate intervals $170-360$ and $460-530 \mathrm{mbsf}$, that is, entirely within the Miocene parts of the succession. None have been observed that have a displacement of more than a few centimeters. In the higher stratigraphic levels, at $\sim 200-220$ mbsf, slump folds and other structures clearly indicative of soft-sediment deformation are preserved. Microthrusts are observed in the axes of some of these slump folds, and these have displacements parallel to the sense of motion of the slumps (Fig. 17). This may suggest that these sediments were being affected by compression very soon after deposition, before or during lithification; their absence in the uppermost portions of the borehole may indicate that the site has not been subjected to compression since that time (upper Miocene?). The microthrusts are, in places, cut by the white hydrothermal veins described above; elsewhere, however, the reverse faults clearly postdate the veins. A clear temporal relationship, therefore, does not appear to exist between the extensional faults and veins and the compressional microfaults.

\section{ORIENTATION OF FAULTS AT SITE 841 \\ Identification and Orientation of Structures Using the FMS}

Structural studies of ODP cores have traditionally suffered from the lack of reliable orientation data, so that structural features could not be set in a geographic context. This has been alleviated somewhat with the introduction by ODP of the FMS downhole logging tool. This tool measures small-scale variations in the electrical conductivity of the formation (usually expressed in terms of resistivity, which is the inverse of conductivity), measured by 16 buttons on each of 4 pads that are pressed against the borehole wall by means of two orthogonal pairs of caliper arms (Ekstrom et al., 1987). Data from each button are processed to form an electrical image of the borehole wall. The theoretical vertical resolution of the tool is $5 \mathrm{~mm}$, but in practice even smaller features can be discerned if they give rise to a sufficiently large resistivity contrast. Small-scale variations in resistivity between different lithologies mean that sedimentary bedding is particularly 


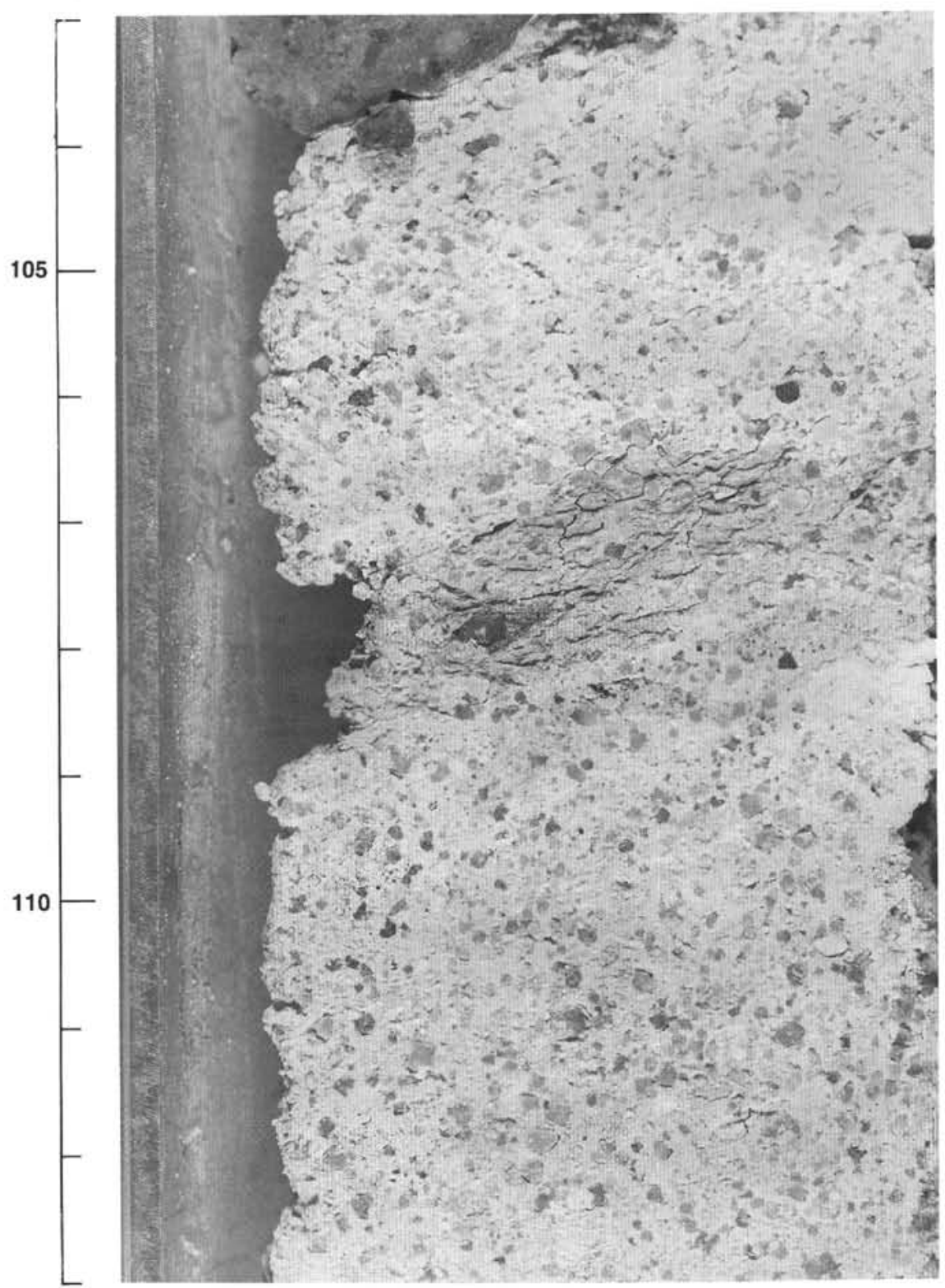

Figure 8. Minor schistose shear strand in mineralized white clay infilling major fault zone at 605 mbsf. Detrital material within the clay is quartz and sulfide; the edge of a larger lava pebble is also visible at the top left-hand corner. Core 135-841B-47R-2, 103-113 cm.

well imaged. Logging data have the significant advantages of continuous vertical coverage of the borehole and, because the FMS tool carries a magnetometer, the reliable orientation of the images to geographical coordinates.

Faults are imaged directly on the FMS records. They are typically marked by subplanar zones of relatively low resistivity, often cutting across and displacing bedding features. The low resistivity signature is a consequence of the enlargement of the borehole that commonly occurs adjacent to faults; in the enlarged zones the pads make imperfect contact with the wall and seawater (with its very low resistivity) contributes to the signal. Some fractures, however, are marked on the FMS images by higher resistivities than the surrounding strata, and these probably denote veins or mineralized fractures. Because the faults are usually associated with borehole enlargement, and the FMS does not make proper contact with the walls, images from the larger fault zones are often of lower quality, and information may not be easy to extract from them. Although many intermediate scale fractures and faults are well imaged by the FMS, few of the microfaults described here from the core are either large or distinctive enough to be visible on the logs. However, the bedding that they cut is usually visible, and the majority of the observed microstructures have been reoriented by matching the core bedding direction (in artificial coordinates) to the FMS bedding direction (in geographical coordinates). This technique is described in detail by MacLeod et al. (this volume).

\section{Faults at Site 841}

Continuous FMS coverage of Hole $841 \mathrm{C}$ was obtained between 71 and $610 \mathrm{mbsf}$. Faults and bedding features were identified and their orientations measured on a MicroVAX workstation using the British Geological Survey log analysis package "FMSBHTV". In Figure 18A a rose diagram of the strikes of 200 fault planes from Hole $841 \mathrm{C}$ identified on the FMS records shows a pronounced northerly to north-northeasterly preferred azimuth. The fault planes dip both to the west and east, although eastward (i.e., trenchward) dips predominate (Fig. 18B). The preference for a near- $000^{\circ}$ direction rather than 


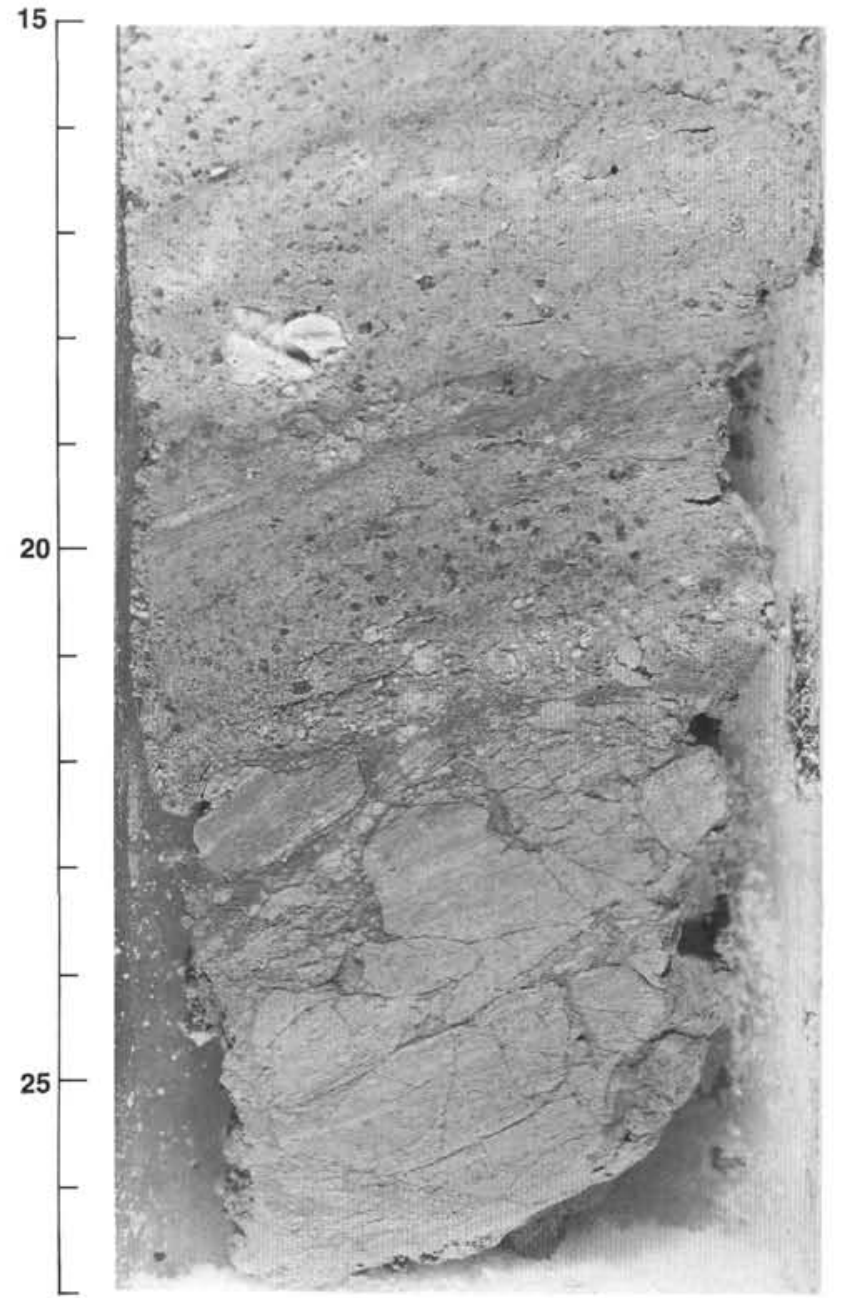

Figure 9. Deformation within mineralized white clay infilling the major fault zone. Note foliated protolith at $22-27 \mathrm{~cm}$ becoming disaggregated and sheared. Core $135-841 \mathrm{~B}-47 \mathrm{R}-\mathrm{CC}, 15-27 \mathrm{~cm}$.

an $020^{\circ}$ trench-parallel strike may be related to local fault control associated with the north-trending terrace mentioned above (see MacLeod and Lothian, this volume).

Core-derived microfault data reoriented using the MacLeod et al. technique (this volume) are shown, undifferentiated, in Figures 18C and 18D, for comparison with the FMS data. The 137 restored microfaults show a similar north-northeast trend to the faults on the FMS logs, although, in contrast, the dominant dip direction to the microfaults is steeply westward (Fig. 18D). Subdivision of the reoriented core data into normal and reverse faults (Figs. 19A and 19B, respectively) shows that it is the normal microfaults that bear the steep westerly dips; virtually all of the gently dipping planes evident in Fig. 18D are reverse faults. The reverse faults display a variety of dips (cf. Fig. 12) and dip directions, with a gently inclined, westward-dipping planes predominating (Fig. 19B). The steep westward dip to the normal fault planes (Fig. 19A) reflects their high angle relative to the bedding (Fig. 12), which, as is shown below, generally dips eastward. The disparity in dip direction between the normal microfaults and the larger scale faults imaged by the FMS suggests that the normal microfaults may be acting as antithetic features to the larger structures. Both the normal and reverse microfaults have predominant trench-parallel strikes. The more northerly preferred azimuth to the restored reverse microfaults is probably not significant, given the small data set $(N=29)$ and shallower dip of the structures (and hence greater errors inherent in the reorientation process; see MacLeod et al., this volume).

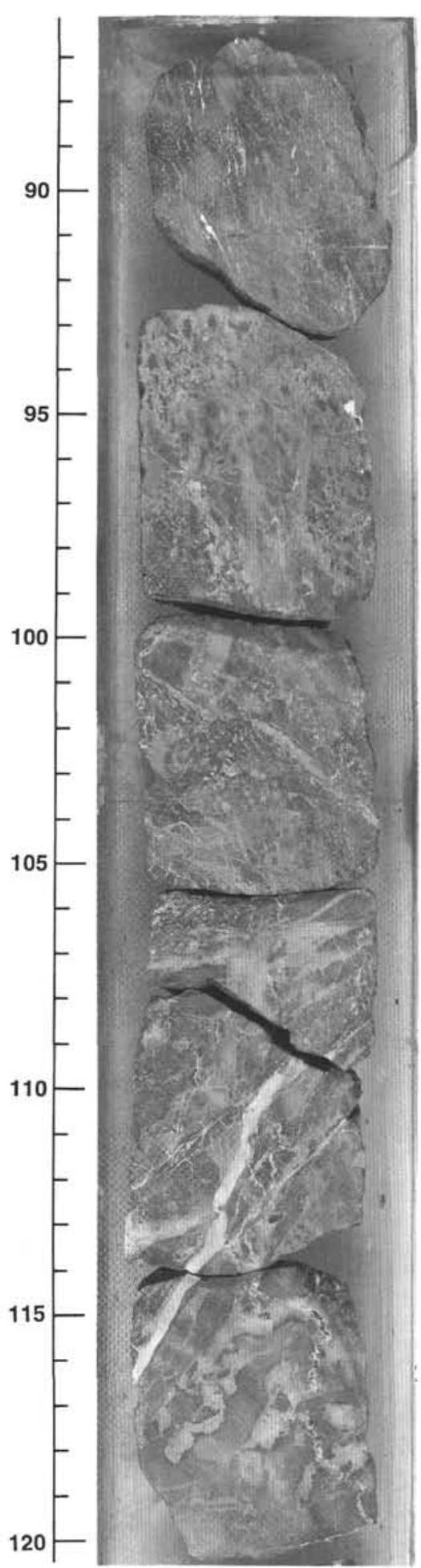

Figure 10. Foliated hydrothermally altered fault rock, from within the zone of leaching of the foot wall of the major fault at 458 mbsf. Core 135-841B-36R-1, $87-120 \mathrm{~cm}$.

The FMS workstation data from the two principal fault zones at Site 841 are shown in Figure 20. For the upper fault zone 21 reliable fault plane orientations were measured within a $40 \mathrm{~m}$ interval between 430 and 470 mbsf. All of the major planes, and the majority overall, dip steeply eastward, and have a marked trench-parallel preferred strike. Of the 23 fault planes identified in the interval $570-610 \mathrm{mbsf}$ 


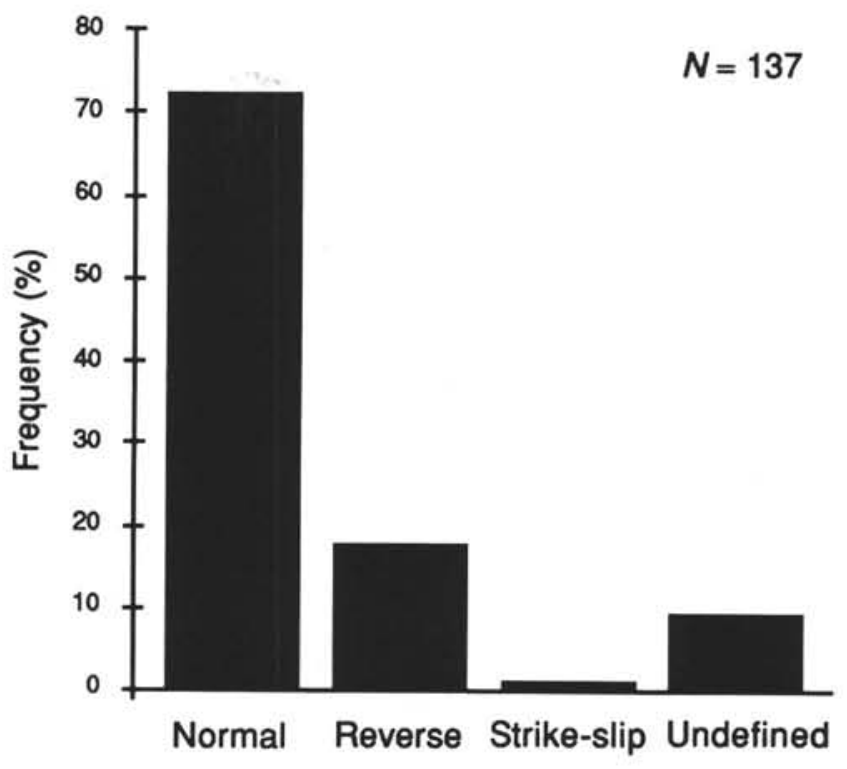

Figure 11. Frequency histogram showing the relative proportions of normal to reverse to strike-slip microfaults whose offsets were identified within cores from Holes 841A and 841B.

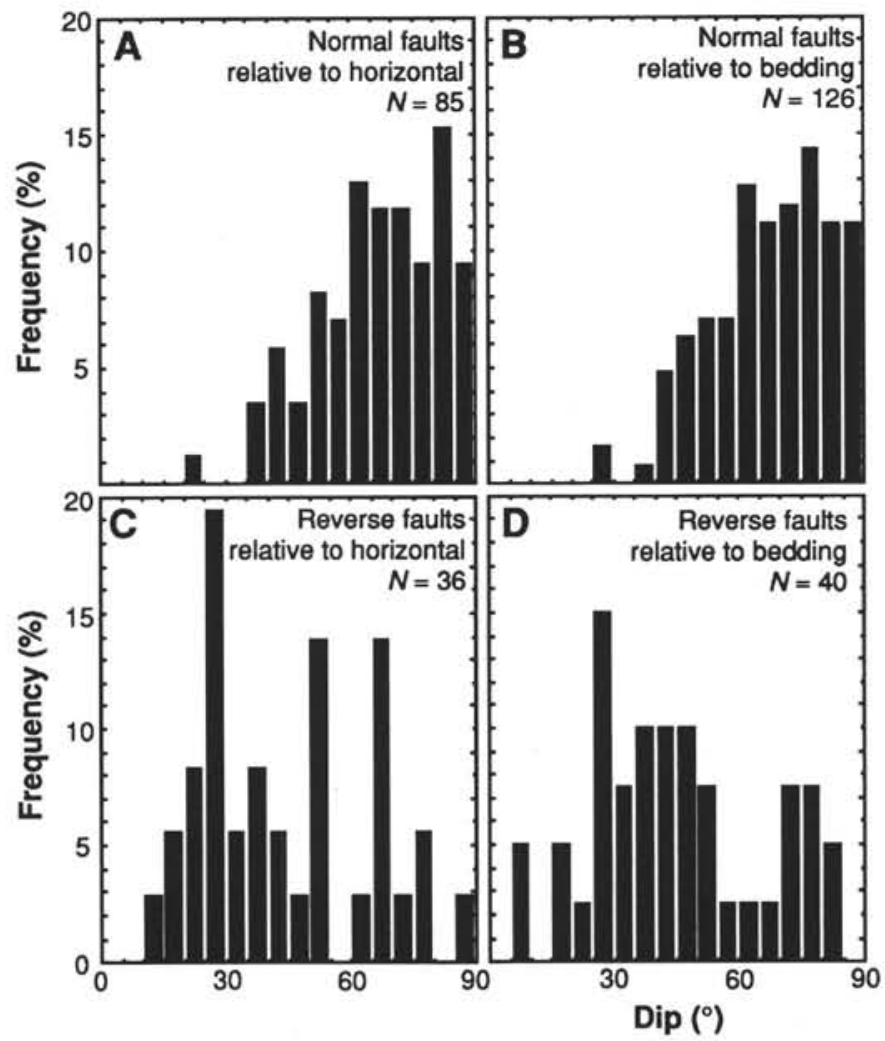

Figure 12. Frequency histograms of the dips of microfaults in cores from Holes $841 \mathrm{~A}$ and $841 \mathrm{~B}$. Above are normal faults measured relative to the horizontal (A) and sedimentary bedding (B). Below are reverse faults, again measured relative to the horizontal (C) and sedimentary bedding (D). In particular, note the steep angle of dip of the normal faults with respect to the bedding.

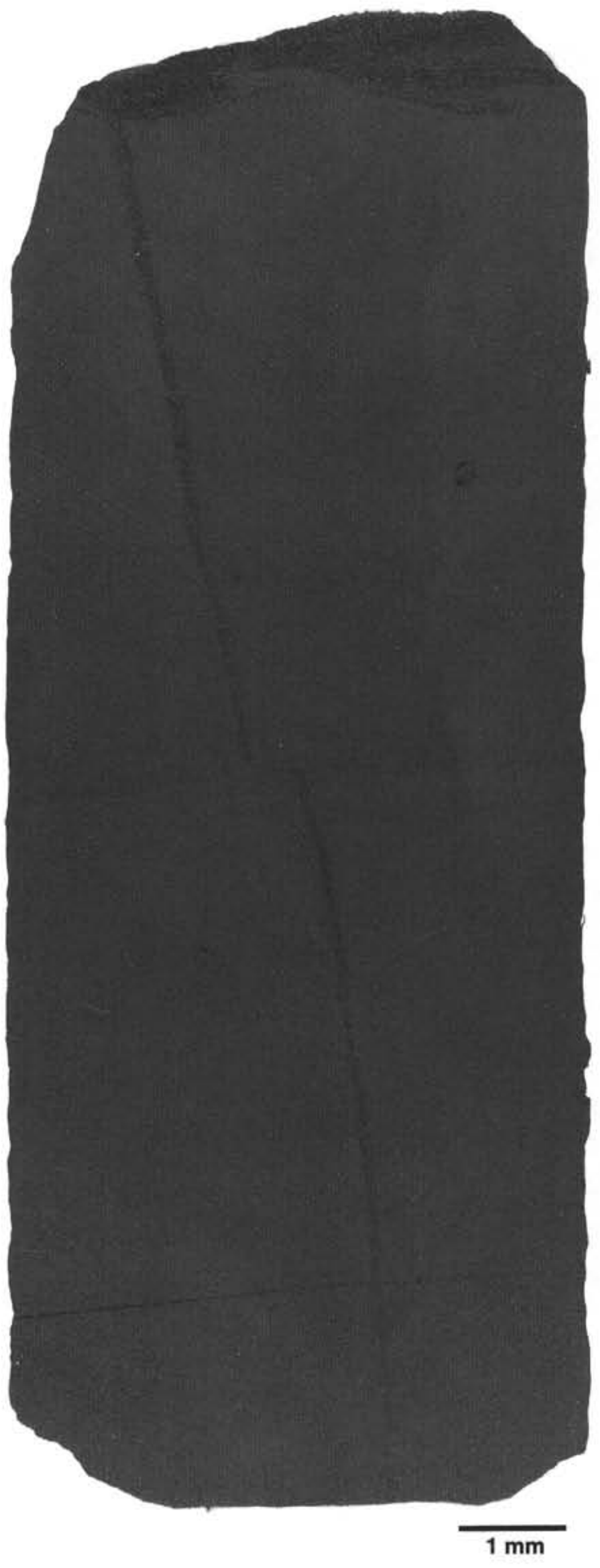

Figure 13. Neptunean dike. Sandstone is injected downward from the top of the core piece into a steeply dipping crack in mudstone. Slight offset of the clastic dike indicates the presence of a small, otherwise undetectable, bedding parallel shear. Core 135-841B-5R-2, 12-25 cm. 


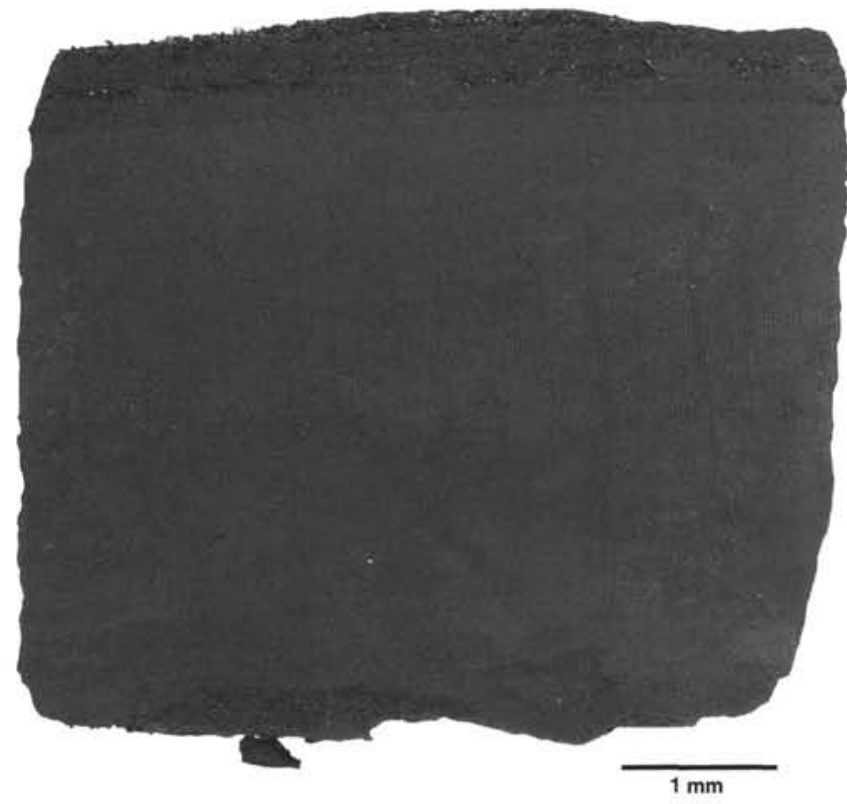

Figure 14. Vein structure in clay-rich sediment. Fractures form perpendicular to the bedding and are interpreted as layer-parallel extensional features. Core 135-841A-2R-1, 108-114 cm.

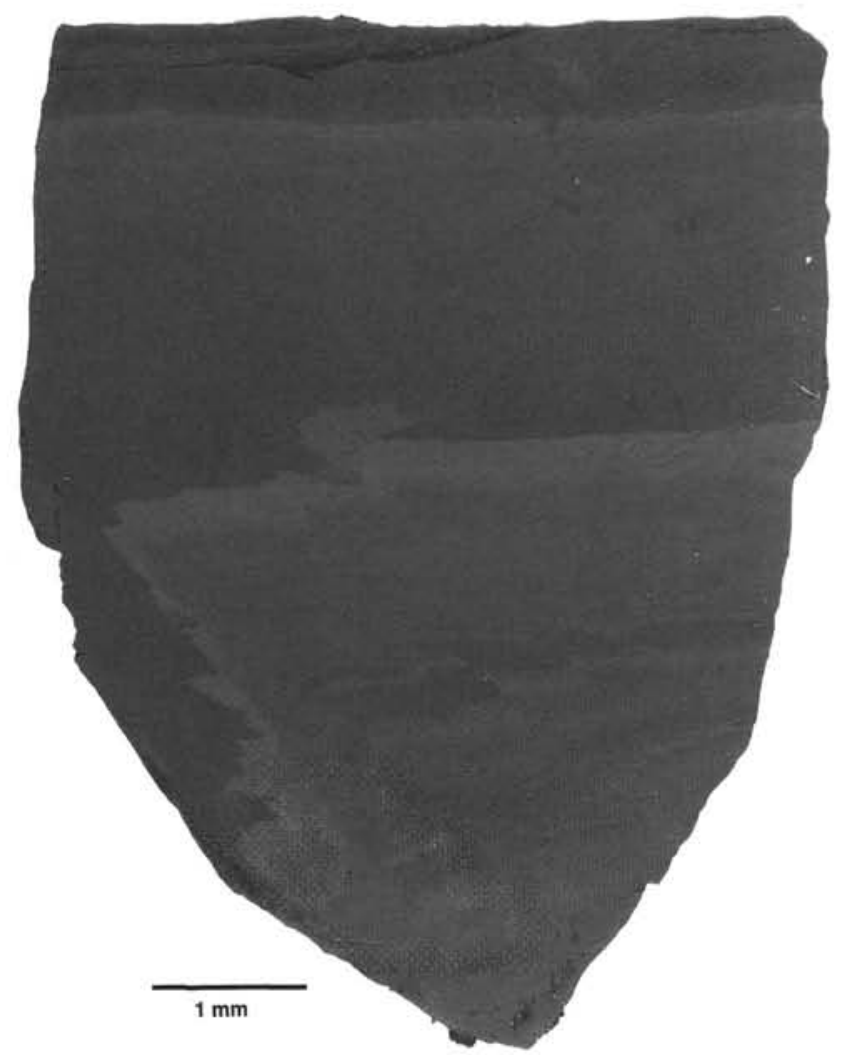

Figure 15. Reverse microfaults in upper Miocene sediments. Core 135-841B$2 \mathrm{R}-1,65-70 \mathrm{~cm}$.

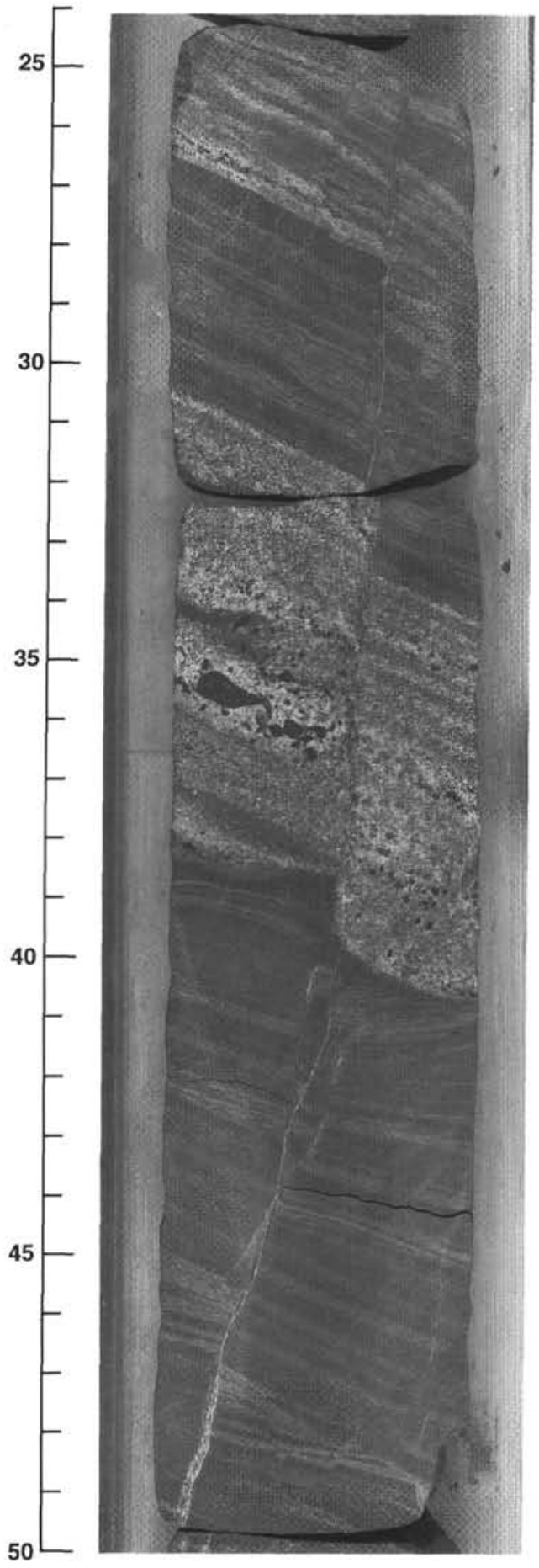

Figure 16. Cemented, steeply dipping fracture cutting turbidite sediments. The fault has an apparent reverse offset but is normal with respect to the bedding; therefore, it is interpreted as a tilted extensional rather than compressional feature. Note that restoration of the core to geographic coordinates (with reference to FMS downhole logs) shows the fault to be trench parallel, with downthrow to the east-southeast. Core 135-841B-37R-3, 27-49 cm. 


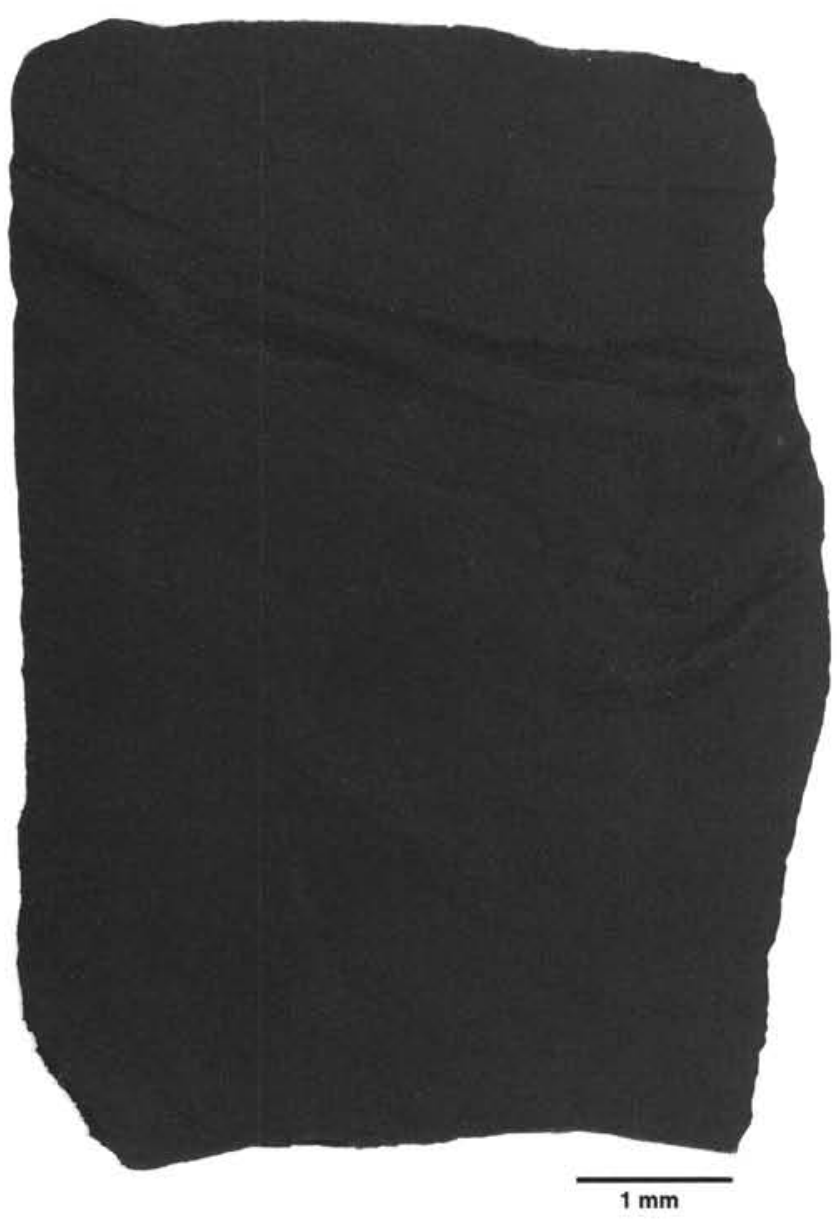

Figure 17. Microthrusts in the hinge of a soft-sediment fold in upper Miocene sediment, possibly indicating early syn-lithification reverse faulting. Core 135-841B-6R-1, 50-57 cm.

from the lower fault zone most also dip trenchward, but less steeply (as do deformation planes in the core at this level; Figs. 8-9) and with a larger range of strikes within the northeast quadrant.

One can conclude from the above observations that the major structures affecting this part of the Tonga forearc are normal faults that parallel the trench. They dip eastward and have displacements that are very probably of the order of hundreds of meters down toward the trench axis. This is supported by GLORIA sidescan sonar imagery of the Tonga Trench, which shows the forearc to be traversed by trenchparallel lineaments that are interpreted as eastward-facing normal fault scarps (Mayer et al., 1990; MacLeod and Lothian, this volume).

\section{SEDIMENTARY BEDDING}

The sedimentary sequence recovered at Site 841 consists of very thin $(\sim 50 \mathrm{~m})$ Pliocene and Pleistocene pelagic oozes overlying approximately $500 \mathrm{~m}$ of middle and upper Miocene volcaniclastic turbidites. These in their turn unconformably overlie lower Oligocene to middle Eocene carbonate-bearing volcaniclastic sediments, the earliest of which are of shallow-water origin, but show evidence of deeper water conditions upsection. Examination of the nature of these sediments and the preservational state of their fauna allows analysis to be made of the subsidence history of the site. This has been investigated by Clift (this volume) and is discussed at the end of this paper.

Much information can also be obtained on the subsidence history and tectonic evolution of the area by examination of sediment orien-
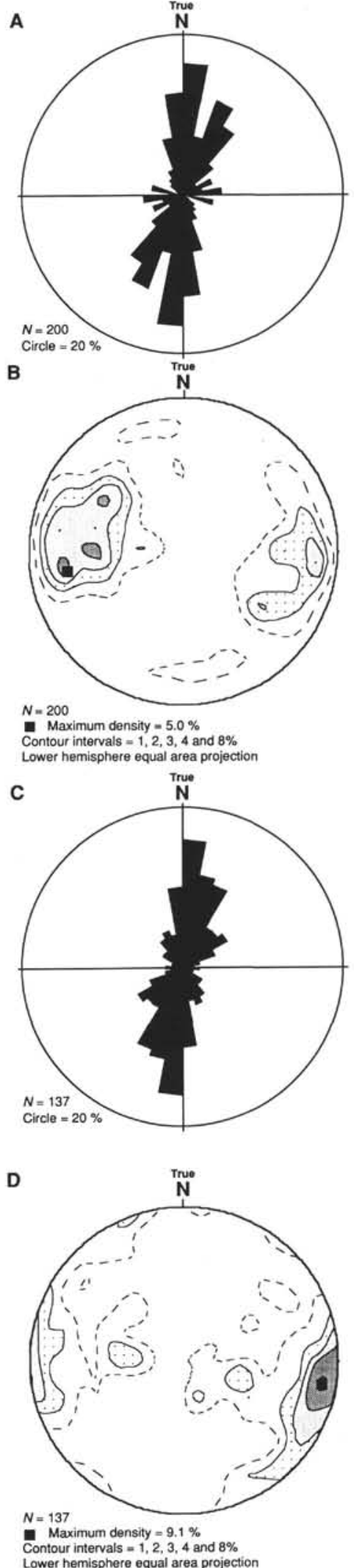

Figure 18. A. Rose diagram of the strike of faults from Hole 841C, based upon FMS workstation measurements. B. Contoured poles to fault planes from the same data set. Note the preponderance of west-dipping poles, corresponding to east-dipping fault planes. Rose diagram (C) and contoured poles to fault planes (undifferentiated; D) from Holes 841A and 841B, reoriented following the technique described in MacLeod et al. (this volume). Note that most poles indicate west-dipping fault planes, in contrast to the data from the FMS logs. Figures $18 \mathrm{~B}$ and $18 \mathrm{D}$ are equal-area lower hemisphere projections. 
A

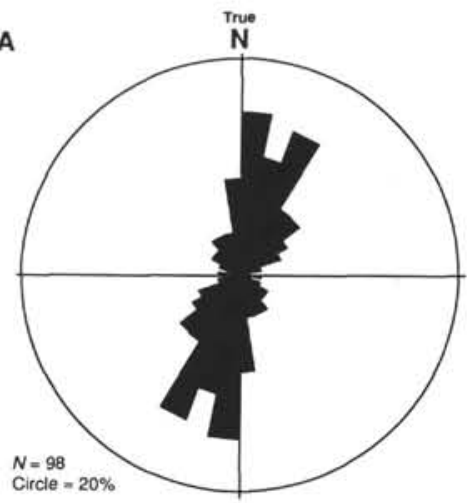

B

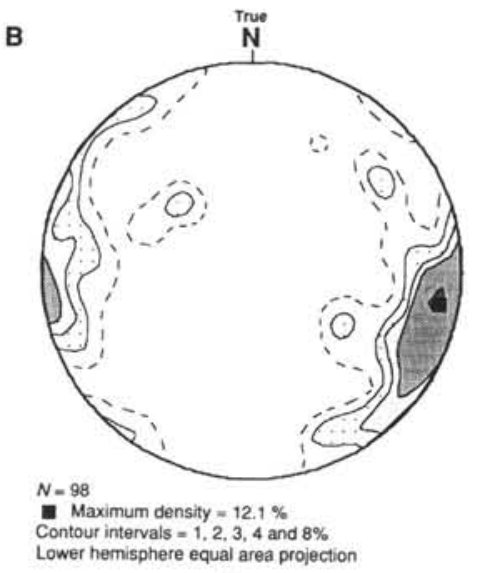

C

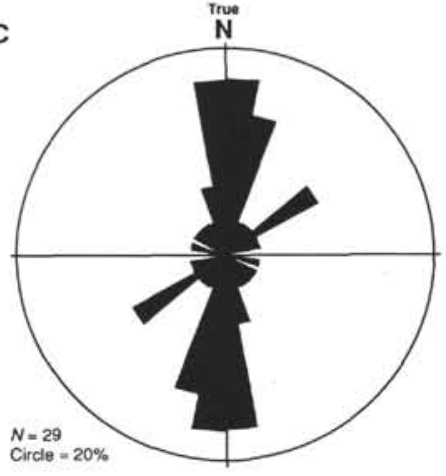

D

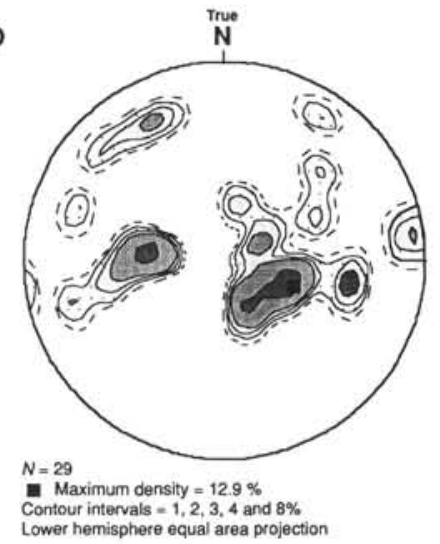

Figure 19. Reoriented structural measurements from cores from Holes $841 \mathrm{~A}$ and $841 \mathrm{~B}$ (Figs. 18C and 18D), differentiated according to fault type. A. Rose diagram of the strike of normal faults from reoriented core measurements from Holes 841A and 841B. B. Contoured poles to fault planes from the same data set. Rose diagram $(\mathbf{C})$ and contoured poles to planes $(\mathbf{D})$ of restored reverse faults from Holes 841 A and 841B. Figures 19B and 19D are equal-area lower hemisphere projections.
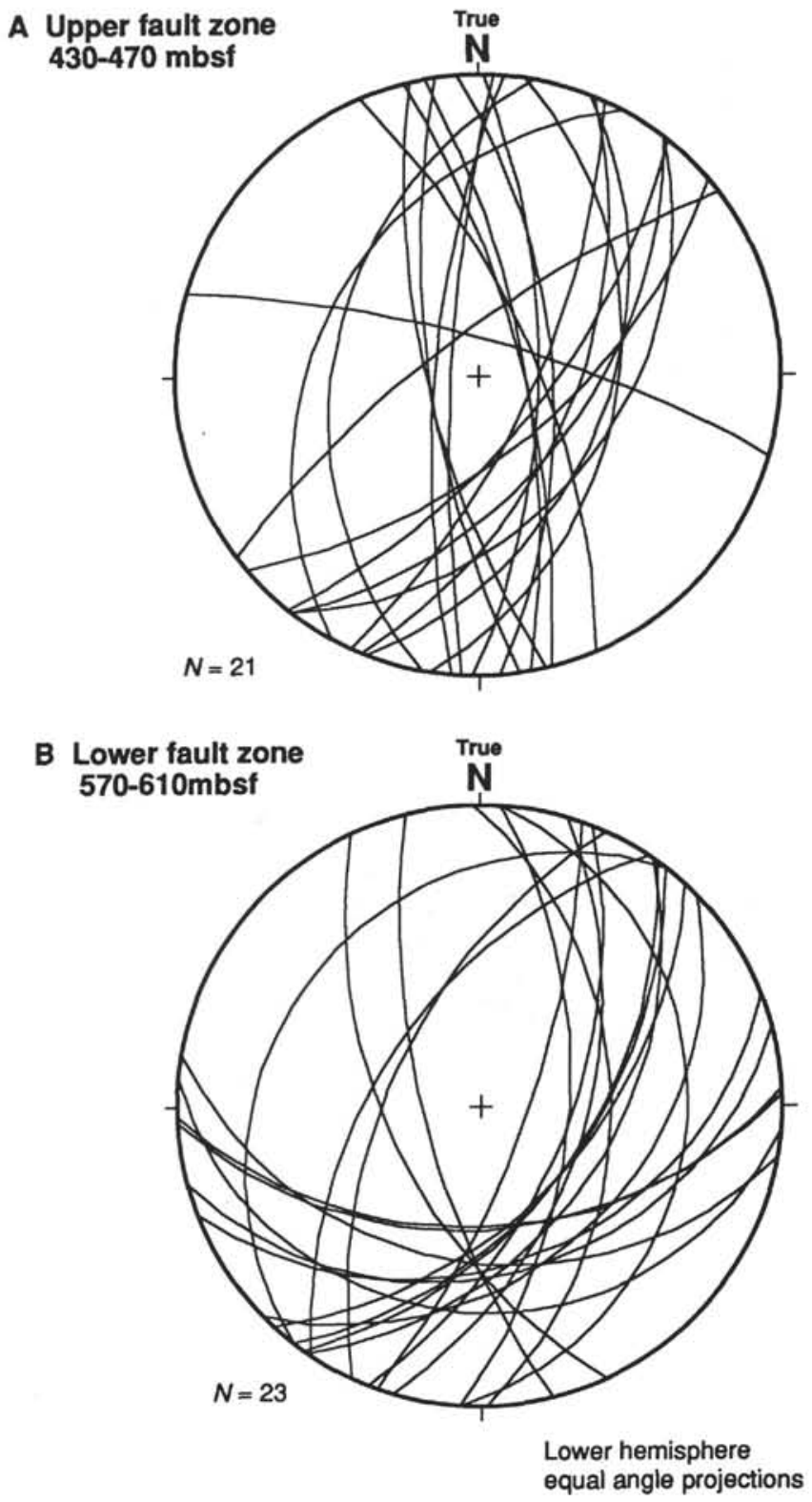

Figure 20. Great circle traces of fault planes from the two principal fault zones of Site 841: (A) upper fault zone (430-470 mbsf) and (B) lower fault zone $(570-610 \mathrm{mbs})$. The data are from faults recognized on FMS images from the intervals adjacent to the fault zones. Equal-angle lower hemisphere projections.

tations. Sedimentary bedding can be regarded as a fundamental strain marker and, thus, is of extreme importance in any analysis of the forearc's deformation history. Sedimentary bedding measurements in the present study are made both from the FMS data and from the core. Core dips are true dips, measured according to the technique described in MacLeod et al. (this volume). Dips from the FMS come either from manual measurement of individual features using the FMS workstation, as described for the tectonic features above, or else from automatic dip computations made during the FMS processing. This "dipmeter" computation is based upon comparison of resistivity responses from the four individual FMS pads: if a statistically significant correlation can be made between the formation resistivities over a given interval on all four pads, then the dipmeter will pick a plane with an orientation calculated from the difference in height between pads. The 
dipmeter computation technique has long been used in the oil industry and is considered to be extremely reliable (Schlumberger, 1986).

\section{Bedding Orientations at Site 841}

Bedding dips from Site 841 are shown in Figures 21-23. The predominant dip direction is eastward (Fig. 21), suggesting that the overall deformation regime is one of downslope tilting and movement into the trench. A smaller number of westerly dip directions in some strata between approximately 350 and 450 mbsf appear to be related to faulting antithetic to the main trenchward tilting direction. Dips range from $0^{\circ}$ to $35^{\circ}$, with a mean of $9^{\circ}$, in the upper $450 \mathrm{~m}$ of the core; however, beneath the fault zone at $450 \mathrm{mbsf}$, they are steeper (Fig. 22). A distinct change in dip and dip direction is observed at $550 \mathrm{mbsf}$, at which depth an unconformity between middle Miocene and lower Oligocene sediments was encountered (Parson, Hawkins, Allan, et al., 1992). Strata below dip eastward rather than southeastward, and have dips that increase rapidly up to almost $70^{\circ}$ in the middle Eocene sediments immediately above the lower fault zone at $605 \mathrm{mbsf}$. The implications of this are discussed below. Stratification in bedded tuffs

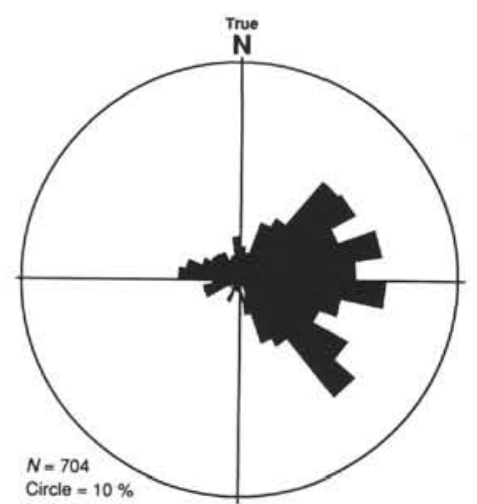

Figure 21. Rose diagram of the dip directions of sedimentary bedding from Site 841 . within the rhyolitic basement display even steeper dips, between $50^{\circ}$ and $80^{\circ}$, but it is unlikely that these were ever indicative of a paleohorizontal (Parson, Hawkins, Allan, et al., 1992).

Dip magnitudes for Site 841 overall (Fig. 23A) are comparable with those from slope sediments at other forearc sites drilled by ODP and the Deep Sea Drilling Project (DSDP), but are closer in their dip frequency distributions to those more actively deforming regions (e.g., the upper slopes of the Japan Trench or Guatemala; cf. Lundberg and Moore, 1986) than to the Mariana Trench, which would otherwise appear to be the most similar to the Tonga Trench in its overall tectonic setting. Lundberg and Moore (1986) speculated that sediment-starved inner trench slopes underlain by igneous substrates, such as those of the Mariana and Tonga forearcs, should be much more rigid than those forearcs associated with significant accretionary prisms, and thus should display sediment dips biased toward much lower mean values. The relatively high frequency of steep bedding dips shown in Figure 23A compared with Lundberg and Moore's compilation for the Mariana region (from DSDP Leg 60 core data) suggests that this part of the Tonga forearc might have been unusually unstable, and/or deforming gradually for a longer period of time. This is explored further below.

Analysis of bedding orientations within and between tectonic units identified above can provide constraints on the deformation history of Site 841. Considering first of all the upper fault zone (at $450 \mathrm{mbsf}$ ), a difference clearly exists in the bedding orientations between sediments above and below it. This may be explained in a number of ways: (1) by rotation of originally parallel units about the fault (i.e., listric normal faulting); (2) from regional tilting events, with differences in dip resulting from the differing ages of the sediments; or, conceivably, (3) by a combination of both of these factors. An assessment of the relative contributions of regional vs. local tectonic effects is made in the following section. Difficulty is noted, however, in explaining the increase of dip (toward the east) below what is unquestionably a normal fault that FMS data (Fig. 20A) show is itself dipping steeply eastward.

The unconformity at 550 mbsf separates middle Miocene planarbedded turbidites (from 450 to $550 \mathrm{mbsf}$ ) dipping regularly southeastward $\left(\right.$ mean dip direction $=135^{\circ}$, dip $=26^{\circ}$; with $\alpha_{95}$ cone of confidence $=4^{\circ}$ ) from Eocene-Oligocene strata (from 550 to 605 mbsf) with mean dip direction $=099^{\circ}$; dip $=32^{\circ}$, and $\alpha_{95}=11^{\circ}$. Subtraction of the mean dip of the overlying from the underlying strata leaves a mean dip to the older sediments of $10^{\circ}$ toward $104^{\circ}$;
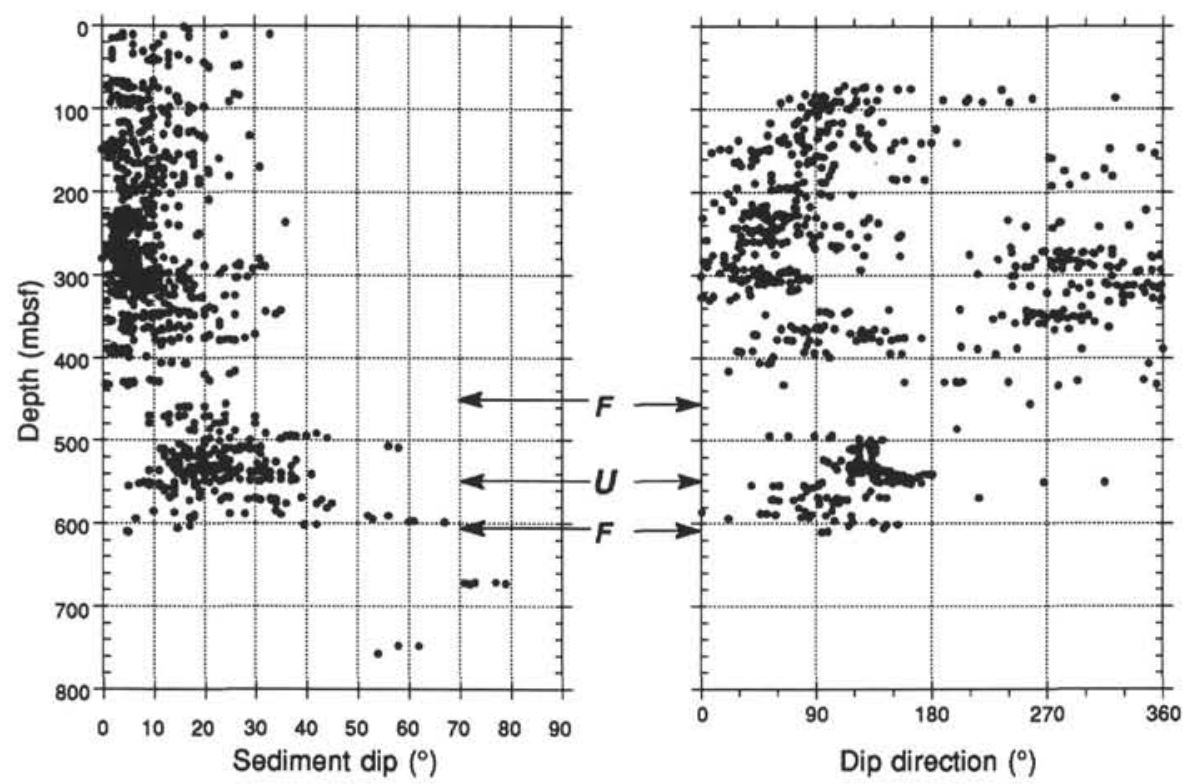

Figure 22. Sediment dip and direction of dip from Site 841. Core-derived measurements are plotted in addition to FMS-derived data. The location of the two principal fault zones recognized in the core are marked with an "F", and the fault zone with the unconformity is marked with a " $\mathrm{U}$ ". 

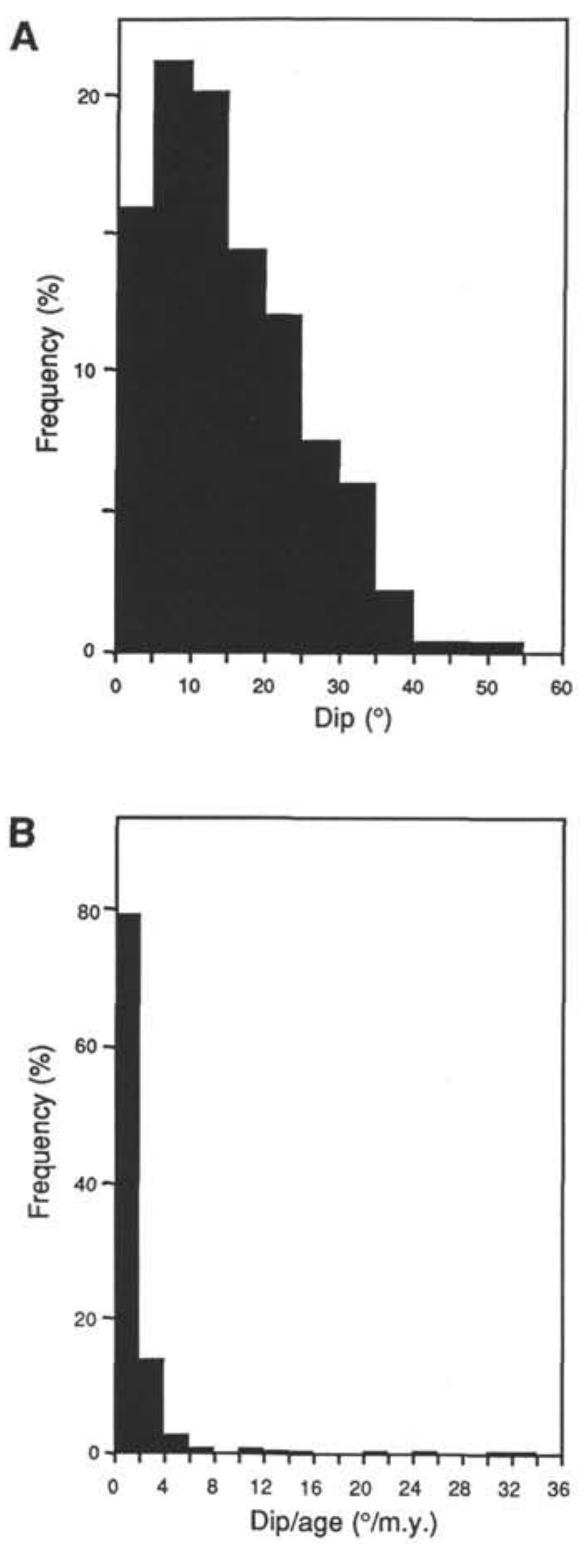

Figure 23. Frequency histograms for core sedimentary bedding data from Holes $841 \mathrm{~A}$ and $841 \mathrm{~B}$. A. Sediment dips. B. Bedding dip divided by sediment age (i.e., "tilting rate"; see text for discussion). $N=266$.

in other words, that the Eocene/Oligocene succession had already been tilted trenchward by $10^{\circ}$ by middle Miocene times. An indication of an increase of dip with depth (at relatively constant azimuth; Fig. 22) between 550 and 605 mbsf suggests in fact that trenchward tilting (by whatever means) of the succession was also occurring during sedimentation in mid Eocene to early Oligocene times. This is investigated more rigorously below.

\section{Tilting Events and Rates of Deformation}

Estimates of the rates of deformation, and ultimately the timing of deformation, can be made by considering the ages of the sediments with respect to the degree of tilting to which they have been subjected. Although the assumption that the Site 841 slope sediments were originally deposited horizontally is unlikely to be true, depositional dips are not likely to be significantly greater than the slope angle, which today is only $2^{\circ}-3^{\circ}$ in the vicinity of the site and would have been, if anything, even less before the Louisville Ridge collision. Estimates of tilt rate, calculated from the dip of a bed divided by its age (as in Fig. 23B, for which ages were determined biostratigraphically from Parson, Hawkins, Allan, et al. [1992]), will therefore be to some extent approximate, but are not affected significantly by such small depositional dips. The tilt rate is remarkably uniform, at between $0^{\circ}$ and $2 \%$ m.y. (mean $1.96 \%$ m.y.; Fig. 23B), with an overall direction of tilting that is consistently trenchward. This tilting rate is comparable to other slope deposits that are founded upon relatively rigid igneous or metamorphic basements, but it contrasts with the far greater spread of tilt rates shown by lower slope deposits in ductilely deforming accretionary prisms (e.g., Mexico; Lundberg and Moore, 1986).

In Figure 23B a small number of very high tilt rates (as high as $32 \%$ m.y.) are indicated for Site 841 . These relate to the steep dips measured from Pleistocene sediments near the mud line in Hole 841 A (Fig. 22), and imply that a tilting "event" must have occurred very recently. We can constrain this by considering the tilt rate throughout the succession; in other words, by plotting the tilt rate against either depth within the borehole (Fig. 24), or sediment age (Fig. 25A). Figure $25 \mathrm{~A}$ (and the expanded Fig. 25B) clearly show that a pronounced tilting episode affected the site approximately $0-0.5$ to $1.5 \mathrm{Ma}$. Another, less pronounced increase in tilt rate is apparent at approximately 4-5 Ma; otherwise, the mean tilt rate is remarkably uniform as far back as the Eocene. The regional significance of these episodes of increased tilting is discussed below. The fact that no change of tilt rate is detectable across the upper fault zone at $450 \mathrm{mbsf}$ (Fig. 24) argues against it being a rotational structure that either increased the dip of sediments below the fault zone or decreased the dip of those above it; instead, the data suggest that a background, regional tilting toward the trench at a rate of $2 \% \mathrm{~m}$.y. has been affecting the forearc since Eocene times.

\section{DISCUSSION}

\section{Subsidence of Site 841: Sedimentary Evidence}

An attempt to model the subsidence history of the Tonga forearc from analysis of the sedimentary records of Sites 840 and 841 has been made by Clift (this volume). Analyses such as this depend critically upon paleowater depth estimates, which are derived principally from sedimentary facies evidence and the composition and state of preservation of fauna. For Site 841 it is clear that the area was very close to sea level in mid to late Eocene times, as demonstrated by the welded tuffs of the rhyolitic basement, and the large foraminifers indicative of very shallow marine conditions in the middle Eocene sediments (Parson, Hawkins, Allan, et al., 1992). Rapid subsidence must have taken place in the late Eocene to early Oligocene, for dissolution of microfossils in the youngest parts of the lower Oligocene succession indicates that it had already subsided into the lysocline $(H$. Nishi, pers. comm., 1992). After the early Oligocene to mid Miocene hiatus, which was almost certainly submarine, the middle Miocene turbidites show little sign of carbonate faunal dissolution and were probably deposited above the lysocline. A shallowing of the carbonate compensation depth (CCD) in the Oligocene (van Andel, 1975) means that uplift did not necessarily have to have occurred during the hiatus. Clear evidence for subsidence through the CCD (postulated to have been at a depth of approximately $4 \mathrm{~km}$ here at this time) is found in the upper Miocene turbidites, and all subsequent sediments were deposited below it (Parson, Hawkins, Allan, et al., 1992).

Clift (this volume) uses the above evidence to reconstruct three distinct "peaks" of accelerated subsidence at Site 841, at approximately 37,15 , and $10-0 \mathrm{Ma}$. These he relates respectively to rifting of the South Fiji Basin, an episode of "subduction rollback," and subduction polarity reversal in the New Hebrides area and breakup of the Vitiaz Arc. However, he sees no subsidence that could be related to the Louisville Ridge collision; at the time at which collision occurred (approximately 1.5 Ma), the site was already below the CCD and thus below the lowermost paleowater depth indicator.

As recognized by Clift (this volume), the subsidence calculations outlined above are very insensitive when water depths as extreme 


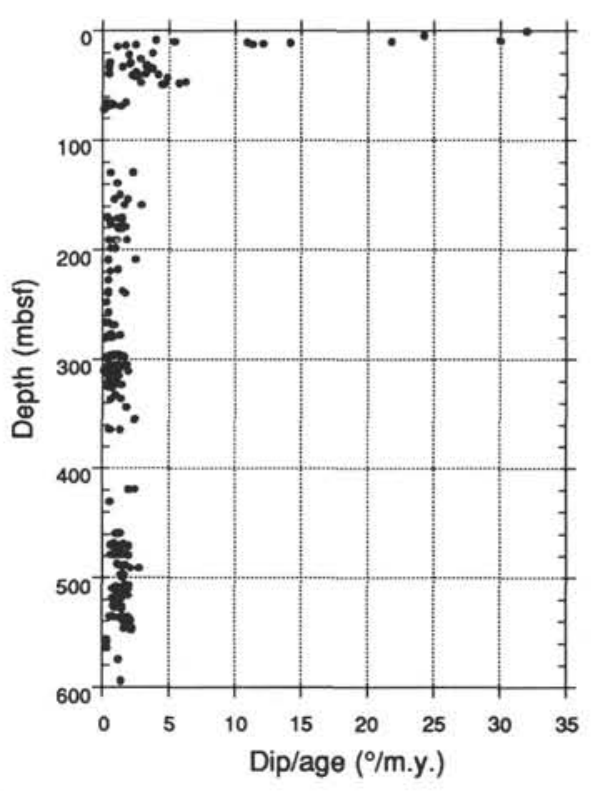

Figure 24. Tilt rate, in degrees per million years, of Site 841 sediments vs. depth within the borehole. The lack of any change of tilt rate across the major fault zone at $450 \mathrm{mbsf}$ suggests that the fault was essentially irrotational. See text for discussion. $N=266$.

as those of the Tonga Trench are encountered. It is difficult to say with certainty from these data how spasmodic the three principal subsidence events really were and, if so, whether they relate to local or regional stimuli. It is possible, for example, that the apparently episodic subsidence could instead be a consequence of punctuated normal fault activity upslope from the site on a structure or structures comparable to the upper fault zone at $450 \mathrm{mbsf}$. One might expect local, trench-related effects to have become progressively more important with time at Site 841 as subduction erosion of the forearc (see below) brought the site ever closer to the trench.

Alternatively, it can be argued that the sedimentological data are equally compatible with more sustained subsidence at intermediate rates, at least through the Miocene. The evidence for relatively uniform rates of trenchward tilting of sediments from the middle Eocene to late Miocene can be taken to support relatively continuous rather than spasmodic subsidence processes. Although subsidence and tilting do not necessarily accompany one another, there is likely to be some relationship, given that the major fault structures are apparently irrotational. Sediments on inner trench slopes tend to assume angles of repose very close to the maximum permitted by gravity; hence they are very sensitive to perturbations in the angle or stability of the slope (e.g., Lallemand and Le Pichon, 1987; von Huene and Culotta, 1989; von Huene and Scholl, 1991).

\section{Louisville Ridge Collision}

Collision and subduction of the Louisville Ridge has had a significant effect on the morphology of the Tonga forearc. Not only has the trench axis been deepened and the inner slope greatly steepened, but a large reentrant some $50 \mathrm{~km}$ wide and $450 \mathrm{~km}$ long has been carved into the forearc in the wake of the collision (Fig. 1; Dupont and Herzer, 1985; Lonsdale, 1986; Ballance et al., 1989), and the debris apparently removed by subduction. Ballance et al. (1989) have proposed that accelerated tectonic erosion of the forearc was a consequence of enhanced fracturing of the overriding plate ahead of the collision, followed by localized uplift during actual subduction of the seamount, and then oversteepening of the inner trench slope and large-scale extensional collapse in its wake.

Oversteepening of the forearc slope in response to Louisville Ridge subduction is very clearly manifest at Site 841 by a marked increase in the rate of tilting of the sedimentary succession toward the
A

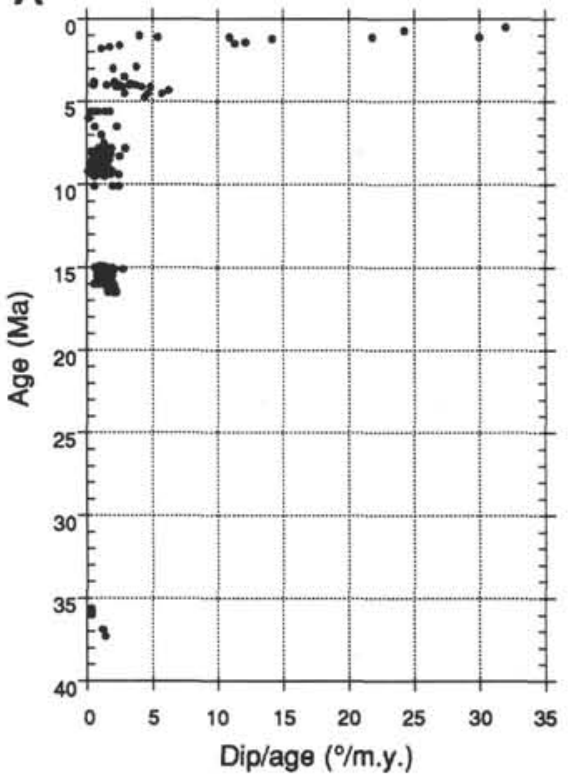

B

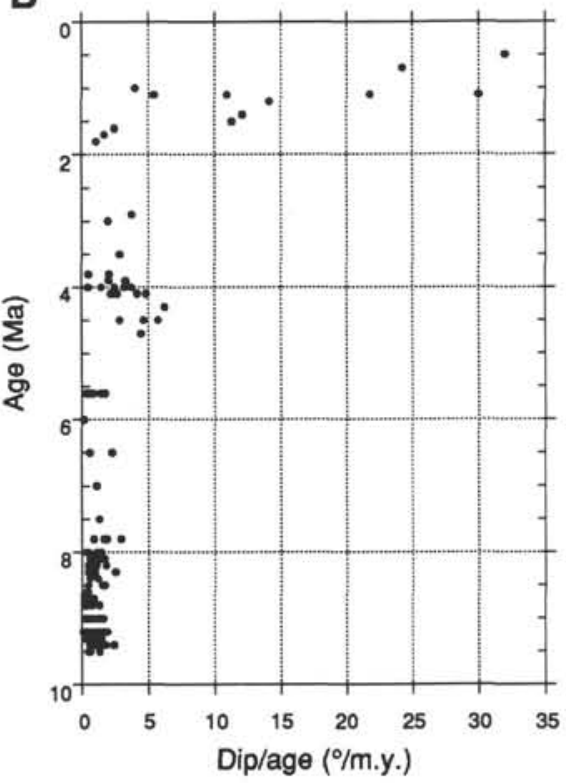

Figure 25. A. Tilt rate, in degrees per million years, of Site 841 sediments vs. age of the sediment. A clear "episode" of markedly increased tilt rate is observed at $1.5 \mathrm{Ma}$. Collision and subduction of the Louisville Ridge are thought to have occurred in the vicinity of Site 841 at approximately 1.5 Ma; thus, it would appear that the collision effected a significant increase in the rate of trenchward tilting of the outer forearc. A lesser peak of accelerated tilting at 4-5 $\mathrm{Ma}$ is also apparent from the graph; rifting of the Tonga-Lau arc complex and opening of the Lau Basin began at approximately this time, and it is conceivable that the tilting is linked to this event. B. Detail of Figure 25A, showing tilt rates over the past $10 \mathrm{~m} . \mathrm{y}$. 
trench axis. Evidence for recent normal faulting, and for layer-parallel extension and bedding-parallel shear in many of the sediments, is compatible with gravity-induced downslope movement of the upper sediment layers. The minor reverse faulting identified within the Site 841 cores (Figs. 15-17) may be related to the initial stages of seamount subduction, before the extensional collapse.

\section{Subsidence and Tectonic Erosion}

Clift's analysis (this volume) cannot tell us how much subsidence accompanied Louisville Ridge collision at Site 841 . What is clear from his work, however, is that the collision was not responsible for the major part of the $5.4 \mathrm{~km}$ of subsidence documented at the site, contrary to the suggestion of Lallemand, Malavieille, and Calassou (1992); all or virtually all of the subsidence must have occurred significantly earlier in the history of the forearc.

In recent years it has been recognized not only that large volumes of upper plate material are routinely eroded and subducted at sedimentstarved convergent margins (reviewed by von Huene and Scholl, 1991), but that wholesale foundering of the forearc may also occur in consequence (e.g., von Huene et al., 1988; von Huene and Culotta, 1989; von Huene and Lallemand, 1990; Lallemand, Schnurle, and Manoussis, 1992). Our findings from the Tonga forearc are not unique: Lallemand, Schnurle, and Manoussis (1992), for example, claim that the forearc above the northern Japan Trench has subsided by more than $6 \mathrm{~km}$ in the past $15 \mathrm{~m}$.y. Furthermore, in these cases subsidence cannot readily be ascribed to "external" causes such as the subduction of ridges or rifting of arcs.

Tectonic erosion in subduction zones may occur by the removal of upper plate material at the foot of the inner trench slope (termed "frontal erosion" by von Huene and Lallemand, 1990). Horsts and graben, with a relief of up to a kilometer, are typically formed in the downgoing slab in response to bending stresses as the plate enters the trench (Lonsdale, 1986; Pontoise et al., 1986; Masson, 1991), and the graben are filled by forearc-derived debris (Hilde, 1983). Recent workers, however, have calculated that the graben-fill physical abrasion process is insufficient to account for the volume of material that is known to be removed (von Huene and Culotta, 1989; von Huene and Lallemand, 1990), and have postulated that large-scale removal of the base of the overriding plate ("basal erosion") also occurs. They think that this process has been helped greatly by overpressured fluids driven from the subducting sediments (Murauchi and Ludwig, 1980; von Huene and Culotta, 1989; von Huene and Lallemand, 1990). For Japan and Peru, von Huene and Lallemand (1990) have calculated that the amount of material removed by basal erosion greatly exceeds that eroded from the front of the slope; consequently, they have attributed the large-scale foundering of the upper plates to the effects of progressive removal of the forearc substrates by basal erosion.

We are not yet at the stage of being able to make numerical calculations of the volumes of material removed by tectonic erosion at the Tonga forearc; therefore, we can only speculate as to whether processes such as those outlined above might be responsible for some or all of the subsidence. Nevertheless, the relatively uniform tilting of the succession at Site 841 toward the trench is indeed compatible with the gradual removal of material from beneath by some basal erosion mechanism, and consequent attempted readjustment of the upper plate. This model need not contradict Clift's hypothesis (this volume) for accelerated periods of subsidence correlating with particular regional events, since such effects can be superimposed upon a background erosion process (see, for example, von Huene et al., 1988). Further work is necessary to integrate the structural and sedimentological constraints from the ODP drilling and use them to attempt to develop a quantitative framework for the controls on vertical motions and tectonic erosion processes at the Tonga convergent margin.

\section{SUMMARY AND CONCLUSIONS}

The Tonga forearc is actively in extension. Site 841 is dominated by the effects of trench-parallel normal faulting at a variety of scales, some of it very recent. Reverse faulting is also observed in the cores, but it is very subordinate. Two major trench-parallel, eastward-dipping normal faults were encountered: an upper fault zone, at $\sim 450$ mbsf, omits much of the middle Miocene succession; and a lower fault zone, at 605 mbsf, separates middle Eocene shallow-water sediments above from a subaerial rhyolitic arc complex below. Total displacement on the upper fault zone is estimated to be on the order of hundreds of meters, possibly as much as a kilometer. Significant alteration is associated with both of the major fault zones, with seawater the most likely hydrothermal fluid.

Bedding orientations from Site 841 show a predominant trenchward dip direction. Dips show a general increase down section, though steep dips are also observed at shallow levels. The rates of tilting of the sediments, however, are very uniform, with the exception of the Pliocene to Recent sediments. These indicate that an episode of oversteepening of the slope and greatly increased trenchward tilting occurred approximately $1.5 \mathrm{Ma}$. This tilting event is synchronous with, and almost certainly a consequence of, subduction of the Louisville Ridge seamount chain beneath the forearc at this latitude. The minor reverse faulting documented in the core may relate to short-lived compressional deformation immediately before ridge subduction.

Although an increase of dip is observed across the upper fault zone at $450 \mathrm{mbsf}$, no change is observed in the tilt rate of the sediments on either side. This suggests that the fault was irrotational, and that the tilting of the sediments is caused by some external, regional process that has operated since Eocene times. Tectonic erosion of the base of the forearc is one such mechanism, and it may explain the massive subsidence that is known to have affected the forearc.

\section{ACKNOWLEDGMENTS}

I would like to thank Sherman Bloomer and Roland von Huene for thoughtful reviews of the manuscript; Peter Clift, Lindsay Parson, and Dietmar Schöps for useful discussions; and Chris Evans for help with the FMS workstation at BGS. Financial support from the Natural Environment Research Council, in the form of an ODP Special Topic Research Grant, is gratefully acknowledged.

\section{REFERENCES}

Ballance, P.F., Scholl, D.W., Vallier, T.L., Stevenson, A.J., Ryan, H., and Herzer, R.H., 1989. Subduction of a Late Cretaceous seamount of the Louisville Ridge at the Tonga Trench: a model of normal and accelerated tectonic erosion. Tectonics, 8:953-962.

Berggren, W.A., Kent, D.V., Flynn, J.J., and Van Couvering, J.A., 1985. Cenozoic geochronology. Geol. Soc. Am. Bull., 96:1407-1418.

Chester, F.M., Friedman, M., and Logan, J.M., 1985. Foliated cataclasites. Tectonophysics, 111:139-146.

Clague, D.A., and Jarrard, R.D., 1973. Tertiary plate motion deduced from the Hawaiian-Emperor Seamount Chain. Geol. Soc. Am. Bull., 84:1135-1154.

Cowan, D.S., 1982. Origin of "vein structure" in slope sediments on the inner slope of the Middle America Trench off Guatemala. In Aubouin, J., von Huene, R., et al., Init. Repts. DSDP, 67; Washington (U.S. Govt. Printing Office), 645-650.

Dupont, J., and Herzer, R.H., 1985. Effect of subduction of the Louisville Ridge on the structure and morphology of the Tonga Arc. In Scholl, D.W., and Vallier, T.L. (Eds.), Geology and Offshore Resources of Pacific Island

\footnotetext{
- Abbreviations for names of organizations and publication titles in ODP reference lists follow the style given in Chemical Abstracts Service Source Index (published by American Chemical Society).
} 
Arcs-Tonga Region. Circum-Pac. Counc. Energy Miner. Resour., Earth Sci. Ser., 2:323-332.

Ekstrom, M.P., Dahan, C., Chen, M.-Y., Lloyd, P., and Rossi, D.J., 1987. Formation imaging with microelectrical scanning arrays. Log Analyst, 28:294-306.

Hilde, T.W.C., 1983. Sediment subduction versus accretion around the Pacific. Tectonophysics, 99:381-397.

Knipe, R.J., 1986. Microstructural evolution of vein arrays preserved in Deep Sea Drilling Project cores from the Japan Trench, Leg 57. In Moore, J.C. (Ed.), Structural Fabric in Deep Sea Drilling Project Cores from Forearcs. Mem.-Geol. Soc. Am., 166:75-87.

Lallemand, S., and Le Pichon, X., 1987. Coulomb wedge model applied to the subduction of seamounts in the Japan Trench. Geology, 15:1065-1069.

Lallemand, S., Malavieille, J., and Calassou, S., 1992. Effects of oceanic ridge subduction on accretionary wedges: experimental modeling and marine observations. Tectonics, 11:1301-1313.

Lallemand, S., Schnurle, P., and Manoussis, S., 1992. Reconstruction of subduction zone paleogeometries and quantification of upper plate material losses caused by tectonic erosion. J. Geophys. Res., 97:217-239.

Lonsdale, P., 1986. A multibeam reconnaissance of the Tonga Trench axis and its intersection with Louisville Guyot Chain. Mar. Geophys. Res., 8:295327.

, 1988. Geography and history of the Louisville Hotspot Chain in the southwest Pacific. J. Geophys. Res., 93:3078-3104.

Lundberg, N., and Moore, J.C., 1986. Macroscopic structural features in Deep Sea Drilling Project cores from forearc regions. In Moore, J.C. (Ed.), Structural Fabrics Preserved in Deep Sea Drilling Project Cores From Forearcs. Mem.-Geol. Soc. Am., 166:13-44.

Masson, D.G., 1991. Fault patterns at outer trench walls. Mar. Geophys. Res., 13:209-225.

Mayer, W., Jacobs, C., and Parson, L.M., 1990. Tectonic and sedimentary processes in the Tonga-Kermadec Trench and adjacent terranes: a GLORIA long-range sidescan sonar survey. Gondwana: Terranes and Resources. Geol. Soc. Austral. Abstr. No. 25, Tenth Austral. Geol. Conv., Hobart.

Mottl, M.J., 1992. Pore waters from serpentinite seamounts in the Mariana and Izu-Bonin forearcs, Leg 125: evidence for volatiles from the subducting slab. In Fryer, P., Pearce, J.A., Stokking, L.B., et al., Proc. ODP, Sci. Results, 125: College Station, TX (Ocean Drilling Program), 373-385.

Murauchi, S., and Ludwig, W.J., 1980. Crustal structure of the Japan Trench: the effect of subduction of ocean crust. In Langseth, M., Okada, H., et al.,
Init. Repts. DSDP, 56, 57 (Pt. 1): Washington (U.S. Govt. Printing Office), 463-469.

Parson, L., Hawkins, J., Allan, J., et al., 1992. Proc. ODP, Init. Repts., 135: College Station, TX (Ocean Drilling Program).

Parson, L.M., et al., 1989. Charles Darwin Cruise 33/88, 5 May-1 June 1988. Geophysical surveying and geological sampling in the Lau back-arc basin, SW Pacific Ocean. Inst. Oceanogr. Sci. Deacon Lab. Cruise Rep., 206.

Parson, L.M., Evans, A.J., and Hunter, P.M., 1992. Bathymetric Charts of the Lau Basin at 1:375,000. Inst. Oceanogr. Sci. Deacon Lab. Rep., Chart 7.

Peacock, S.M., 1990. Fluid processes in subduction zones. Science, 248:329337.

Pontoise, B., Pelletier, B., Aubouin, J., Baudry, N., Blanchet, R., Butscher, J., Chotin, P., Diament, M., Dupont, M., Eissen, J., Ferrière, J., Herzer, R., Lapouille, A., Louat, R., d'Ozouville, L., Soakai, S., and Stevenson, A., 1986. Subduction of the Louisville Ridge along the Tonga Trench: preliminary results of SEAPSO campaign (Leg V). C. R. Acad. Sci. Ser. 2, 10:911-918.

Schlumberger, 1986. Dipmeter Interpretation Fundamentals: New York (Schlumberger), SMP-7002.

van Andel, T.H., 1975. Mesozoic-Cenozoic calcite compensation depth and the global distribution of calcareous sediments. Earth Planet. Sci. Lett., 26:187-194.

von Huene, R., and Culotta, R., 1989. Tectonic erosion at the front of the Japan Trench convergent margin. Tectonophysics, 160:75-90.

von Huene, R., and Lallemand, S., 1990. Tectonic erosion along the Japan and Peru convergent margins. Geol. Soc. Am. Bull., 102:704-720.

von Huene, R., and Scholl, D.W., 1991. Observations at convergent margins concerning sediment subduction, subduction erosion, and the growth of the continental crust. Rev. Geophys., 29:279-316.

von Huene, R., Suess, E., and the ODP Leg 112 Scientific Party, 1988. Ocean Drilling Program Leg 112, Peru continental margin. Part 1: tectonic history. Geology, 16:934-938.

Watts, A.B., Weissel, J.K., Duncan, R.A., and Larson, R.L., 1988. Origin of the Louisville Ridge and its relationship to the Eltanin Fracture Zone. J. Geophys. Res., 93:3051-3077.

Date of initial receipt: 2 July 1992

Date of acceptance: 28 July 1993

Ms 135SR-157 